\title{
The Effects of the Financial Crisis on Photovoltaics: An Analysis of Changes in Market Forecasts from 2008 to 2009
}

John E. Bartlett

New West Technologies, LLC

Robert M. Margolis

National Renewable Energy Laboratory

Charles E. Jennings

Financial Analytics Consulting Corporation

Technical Report NREL/TP-6A2-46713

September 2009 


\section{The Effects of the Financial Crisis on Photovoltaics: An Analysis of Changes in Market Forecasts from 2008 to 2009}

John E. Bartlett

New West Technologies, LLC

Robert M. Margolis

National Renewable Energy Laboratory

Charles E. Jennings

Financial Analytics Consulting Corporation

Prepared under Task No. PVD9.1210

National Renewable Energy Laboratory

1617 Cole Boulevard, Golden, Colorado 80401-3393

303-275-3000 • www.nrel.gov

NREL is a national laboratory of the U.S. Department of Energy

Office of Energy Efficiency and Renewable Energy

Operated by the Alliance for Sustainable Energy, LLC

Contract No. DE-AC36-08-GO28308 


\section{NOTICE}

This report was prepared as an account of work sponsored by an agency of the United States government. Neither the United States government nor any agency thereof, nor any of their employees, makes any warranty, express or implied, or assumes any legal liability or responsibility for the accuracy, completeness, or usefulness of any information, apparatus, product, or process disclosed, or represents that its use would not infringe privately owned rights. Reference herein to any specific commercial product, process, or service by trade name, trademark, manufacturer, or otherwise does not necessarily constitute or imply its endorsement, recommendation, or favoring by the United States government or any agency thereof. The views and opinions of authors expressed herein do not necessarily state or reflect those of the United States government or any agency thereof.

Available electronically at http://www.osti.gov/bridge

Available for a processing fee to U.S. Department of Energy and its contractors, in paper, from:

U.S. Department of Energy

Office of Scientific and Technical Information

P.O. Box 62

Oak Ridge, TN 37831-0062

phone: 865.576 .8401

fax: 865.576 .5728

email: mailto:reports@adonis.osti.gov

Available for sale to the public, in paper, from:

U.S. Department of Commerce

National Technical Information Service

5285 Port Royal Road

Springfield, VA 22161

phone: 800.553 .6847

fax: 703.605.6900

email: orders@ntis.fedworld.gov

online ordering: http://www.ntis.gov/ordering.htm 


\section{Acknowledgments}

The authors would like to thank the following people for providing helpful comments on draft versions of this report: Karlynn Cory (National Renewable Energy Laboratory), Sam Dubinsky (Oppenheimer \& Co), Vishal Shah (Barclays Capital) and Christopher Cameron (Sandia National Laboratories). The authors also thank Nick Allen (Morgan Stanley), Joe Balzano (Lazard Capital Markets), Hari Chandra (Deutsche Bank), Jenny Chase and Julia Wu (New Energy Finance), Brian Lee (Citi Investment Research), Jeff Osborne (Thomas Weisel Partners), Robert Stone (Cowen \& Company), Ted Sullivan (Lux Research) and Ahmar Zaman (UBS Investment Research) for sharing their insights on the photovoltaic industry. The authors are grateful for funding support from the U.S. Department of Energy. 


\section{Table of Contents}

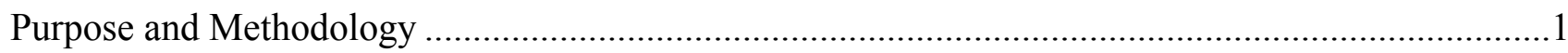

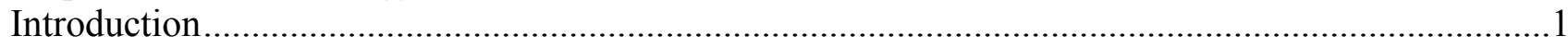

Polysilicon and PV Module Production Forecasts....................................................................

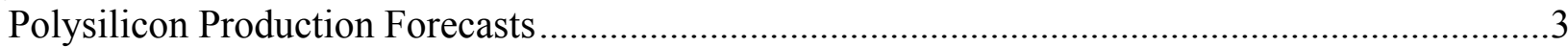

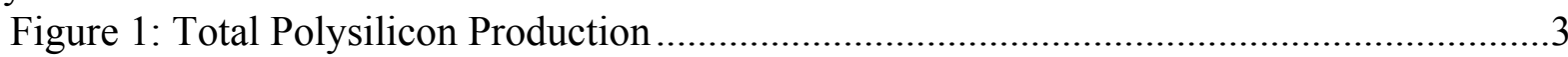

Figure 2: Polysilicon Production by Technology .................................................................

Figure 3: Polysilicon Production by End Market ………....................................................

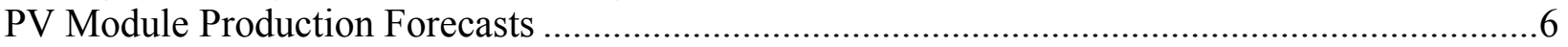

Figure 4: Total PV Module Production .......................................................................6

Figure 5: C-Si PV Module Production..............................................................................

Figure 6: Thin Film PV Module Production..........................................................................

Figure 7: Thin Film PV Module Production by Technology ..................................................

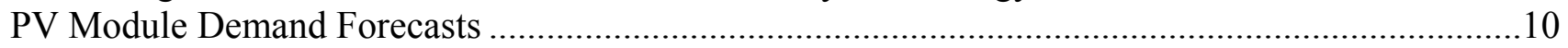

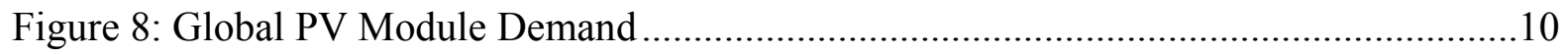

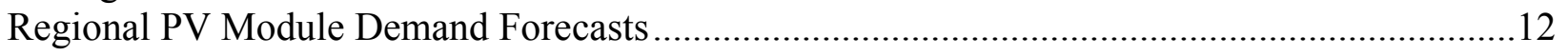

Figure 9: Europe PV Module Demand ........................................................................12

Figure 10: North America PV Module Demand...............................................................13

Figure 11: Japan and South Korea PV Module Demand ......................................................14

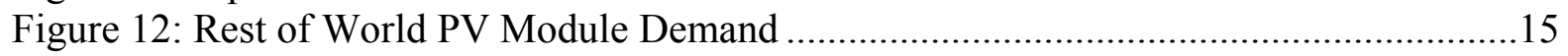

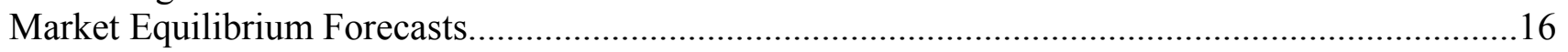

Figure 13: PV Module Production versus Demand ........................................................16

Figure 14: Blended Polysilicon Prices ..........................................................................18

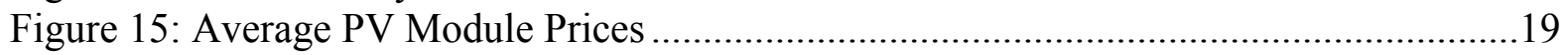

Figure 16: Average PV System Prices..........................................................................20

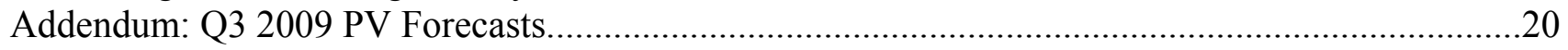

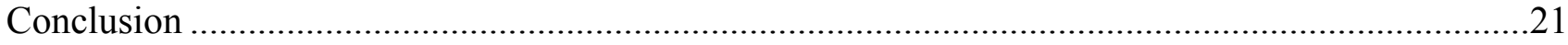

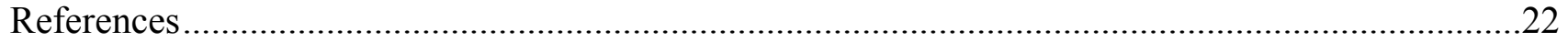




\section{Purpose and Methodology}

For the capital-intensive photovoltaic sector, the tightening of credit resulting from the global financial crisis has the potential to significantly inhibit the industry's growth. More expensive and less available financing diminishes both PV demand, by making photovoltaic installations less attractive and more difficult investments, as well as PV supply, by curtailing the expansion of photovoltaic manufacturing capacity. Indirect effects from the financial crisis, such as lower wealth and income, reduced natural gas prices and expansionary fiscal policies, are also likely to affect the PV sector.

To better understand the effects of the financial crisis on the photovoltaic industry, we surveyed the market forecasts of industry analysts, provided that they had issued projections during both the third quarter of 2008 and the first quarter of 2009. ${ }^{1,2,3}$ While this sample cannot capture the entire range of opinions about the PV industry, it includes analysts from over a dozen financial, research and consulting firms that closely follow the sector. In this paper, we analyze the median and range of the forecasts made in Q3 2008 and Q1 2009 as well as the median and range of changes in forecasts made by the same analyst. From this analysis, we infer how the financial crisis has impacted industry expectations of supply, demand and pricing over the next several years.

\section{Introduction}

The photovoltaic industry requires substantial inflows of investment to finance corporations and projects. With respect to corporate finance, investment is generally in the form of government grants, venture capital, private equity, corporate debt and public equity. Depending on the company's size and stage of development, these various types of investment enable corporate operations and expansion. With respect to project finance, investment is generally in the form of debt, tax equity and private equity. Project finance is necessary for the development, construction and operation of PV installations.

The financial crisis has affected all types of PV investment, but the effect has not been equal, in direction or magnitude. For example, whereas public equity investment in photovoltaic companies declined by almost two-thirds from Q4 2007 to Q4 2008, venture capital and private equity investments in PV companies rose by over a third during this period. ${ }^{4}$ While venture capital and private equity are not invulnerable to the financial crisis (VC and PE investments in photovoltaic

\footnotetext{
${ }^{1}$ Since industry research reports are often published infrequently and there is a lag between research and publication dates, some of the reports from Q3 2008 were published towards the end of Q2 2008 or around the beginning of Q4 2008. Likewise, some of the reports from Q1 2009 were actually published at the beginning of Q2 2009. Dates for each of the reports are noted in the references.

${ }^{2}$ While the financial crisis has its origins in the latter half of 2007, it was not until the bankruptcy of Lehman Brothers, the Federal Reserve Bank's loan to AIG, the sale of Merrill Lynch to Bank of America in September 2008 and the resulting tightening of credit that the full extent of the crisis became apparent. The end of 2008 is thus a sensible division between pre-crisis and post-crisis forecasts.

${ }^{3}$ For each PV and polysilicon forecast, with the sole exception of that for polysilicon prices, we required estimates from a minimum of four analysts to ensure a range of opinions.

${ }^{4}$ New Energy Finance Desktop 3.0, http://www.newenergymatters.com, accessed May 20, 2009.
} 
companies declined by over half between Q4 2008 and Q1 2009), they are more insulated from financial shocks than many other types of investment. ${ }^{5}$ In addition, the duration of use varies significantly between types of investment. While venture capital, private equity and public equity investments may be used over several years for company growth, project finance debt may need to be spent quickly for the purchase of PV systems to take advantage of global subsidy rates that tend to decline annually. The effect of declining investment may thus have a more immediate impact on project development than corporate expansion. Differences among sensitivities of investment to the financial crisis and in duration of investment use imply that certain areas of the photovoltaic industry will be more adversely impacted than others.

While changes in investment are the most direct effects on PV of the financial crisis, there are also important indirect effects. First, the financial crisis and global recession have resulted in lower wealth and income, which will likely lower the aggregate demand for electricity as well as consumers' willingness-to-pay for environmental initiatives. ${ }^{6}$ Second, commodity prices, particularly that of natural gas, have dropped significantly over the past year as the economic downturn has intensified. In markets where PV-generated electricity is a substitute for natural gasgenerated electricity, demand for PV will decline as a result. Lastly, the financial crisis and global recession have prompted expansionary monetary and fiscal public policies. Fiscal policies promoting renewable energy through tax credits, rebates, government expenditures and other mechanisms will likely increase both demand and supply of PV. ${ }^{7}$

In Section 1, we examine the Q3 2008 and Q1 2009 forecasts for polysilicon production, by end market and by technology, and PV module production, including crystalline silicon (c-Si) and thin film technologies. In Section 2, we analyze the two sets of forecasts for photovoltaic module demand, both globally and on a regional level. After comparing production with demand forecasts in Section 3, we examine price estimates for polysilicon, PV modules and PV systems. Finally, we offer conclusions about the effect of the financial crisis and the current outlook for the photovoltaic industry.

\footnotetext{
${ }^{5}$ Ibid.

${ }^{6}$ For example, the EIA Annual Energy Outlook 2009 reduced its forecast for 2015 electricity use by $2 \%$ compared to its 2008 estimate. In markets that have Renewables Portfolio Standards (RPSs), such as many states in the U.S., a drop in electricity demand will reduce the amount of renewable energy needed to meet the RPS.

${ }^{7}$ However, the financial crisis could also have the effect that governments are forced to cut incentive programs for renewable energy due to lack of funds.
} 


\section{Polysilicon and PV Module Production Forecasts}

Polysilicon and PV module production are capital-intensive industries, and thus the growth of both sectors is vulnerable to a reduction in available financing. ${ }^{8}$ Furthermore, a decrease in future demand for PV will diminish the need for greater module production, which in turn will lower the need for additional polysilicon. Polysilicon production is worthy of individual attention, as it is the feedstock for a large majority of photovoltaic modules and has historically experienced large fluctuations in price.

\section{Polysilicon Production Forecasts}

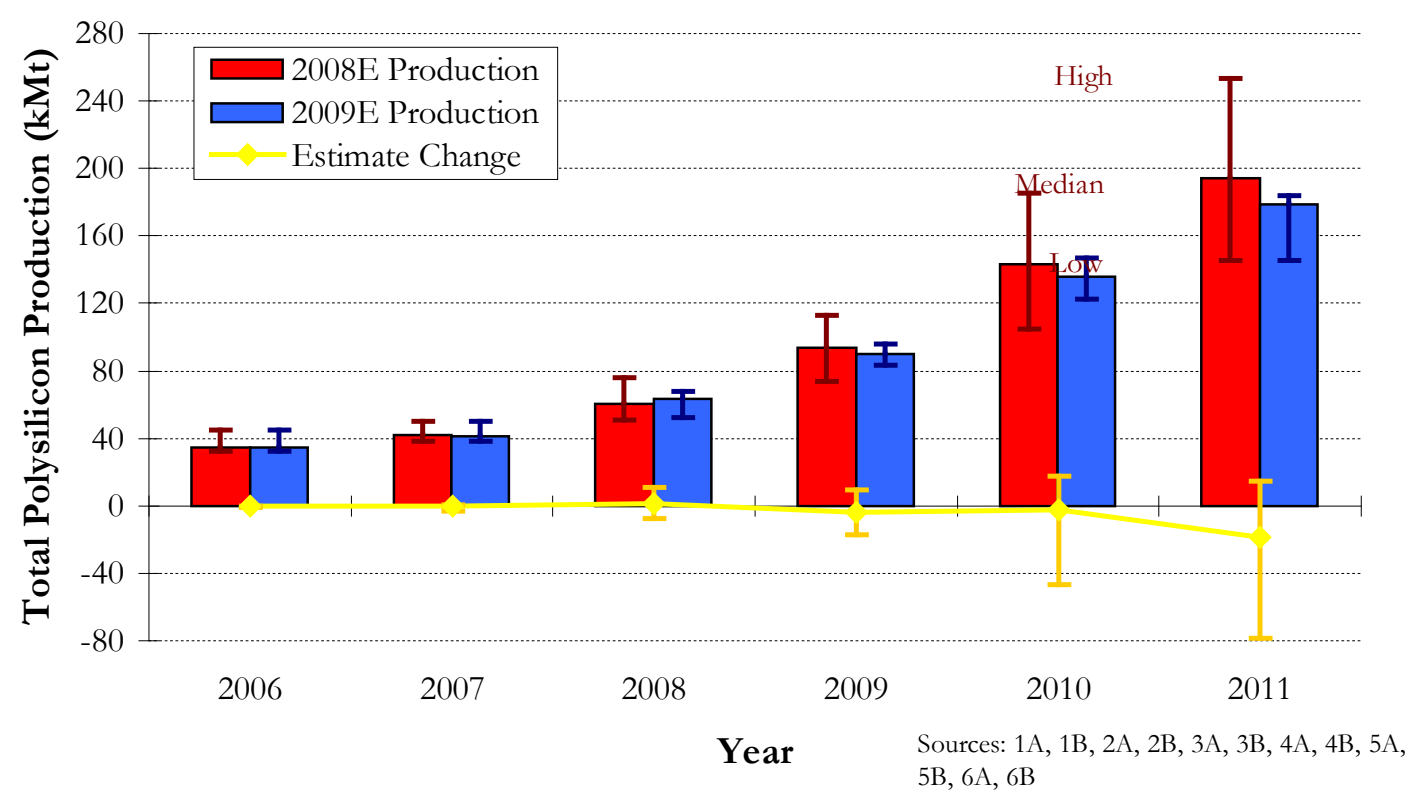

Figure 1. Total polysilicon production

Figure 1 shows the forecasts for total polysilicon production and how those forecasts have changed between Q3 2008 and Q1 2009. The median estimates did not change substantially, with the median forecasts for 2010 and 2011 declining by only $5 \%$ and $8 \%$, respectively. Despite the effects of the financial crisis, industry analysts still expect polysilicon production to grow from about $64 \mathrm{kMt}$ in 2008 to $179 \mathrm{kMt}$ in 2011, a compound annual growth rate (CAGR) of $41 \%$. However, the range of forecasts narrowed considerably, particularly the spread between the median and high estimates. For 2011, the high estimate decreased from over $253 \mathrm{kMt}$ to less than $184 \mathrm{kMt}$. As shown in the Estimate Change line, one of the analysts lowered his forecast for 2011 polysilicon production by almost $80 \mathrm{kMt}$.

That the median estimates did not change significantly reflects the two determinants of polysilicon production, utilization and capacity, which cause production to be somewhat insensitive to current market conditions. First, the relatively low marginal costs of production result in high

\footnotetext{
${ }^{8}$ We analyze polysilicon and PV module production rather than supply or shipments, as production is presented more consistently across analysts.
} 
utilization rates, even when polysilicon prices decline. ${ }^{9}$ Second, the construction of polysilicon plants is time and capital-intensive, resulting in a delay of several years between planned and realized capacity additions. The long duration has the effect that polysilicon production capacity is slow to adjust to current market conditions, as was evident in early 2008 when a shortage of polysilicon resulted in spot market prices of $\$ 500$ per kilogram. ${ }^{10}$ Conversely, even though future demand for PV modules (and thus polysilicon) has recently declined, additional polysilicon production capacity in various stages of development will still be coming on line over the next few years.

While the financial crisis had only a modestly adverse impact on median estimates, the high estimates for polysilicon production dropped markedly. In examining the differential effects of the financial crisis, it is important to distinguish new polysilicon capacity by incumbent producers, which is comparatively probable, from new capacity by new producers, which is less certain. Prior to the crisis, analysts with higher estimates had assumed a greater probability of success for new producers than had more conservative analysts. However, the financial crisis caused the more optimistic analysts to significantly reduce their estimates of additional capacity from new producers, which are more vulnerable to a tight credit environment. This narrowed the differences of opinion among analysts. It is notable that the low estimate for 2011 polysilicon production remained unchanged.

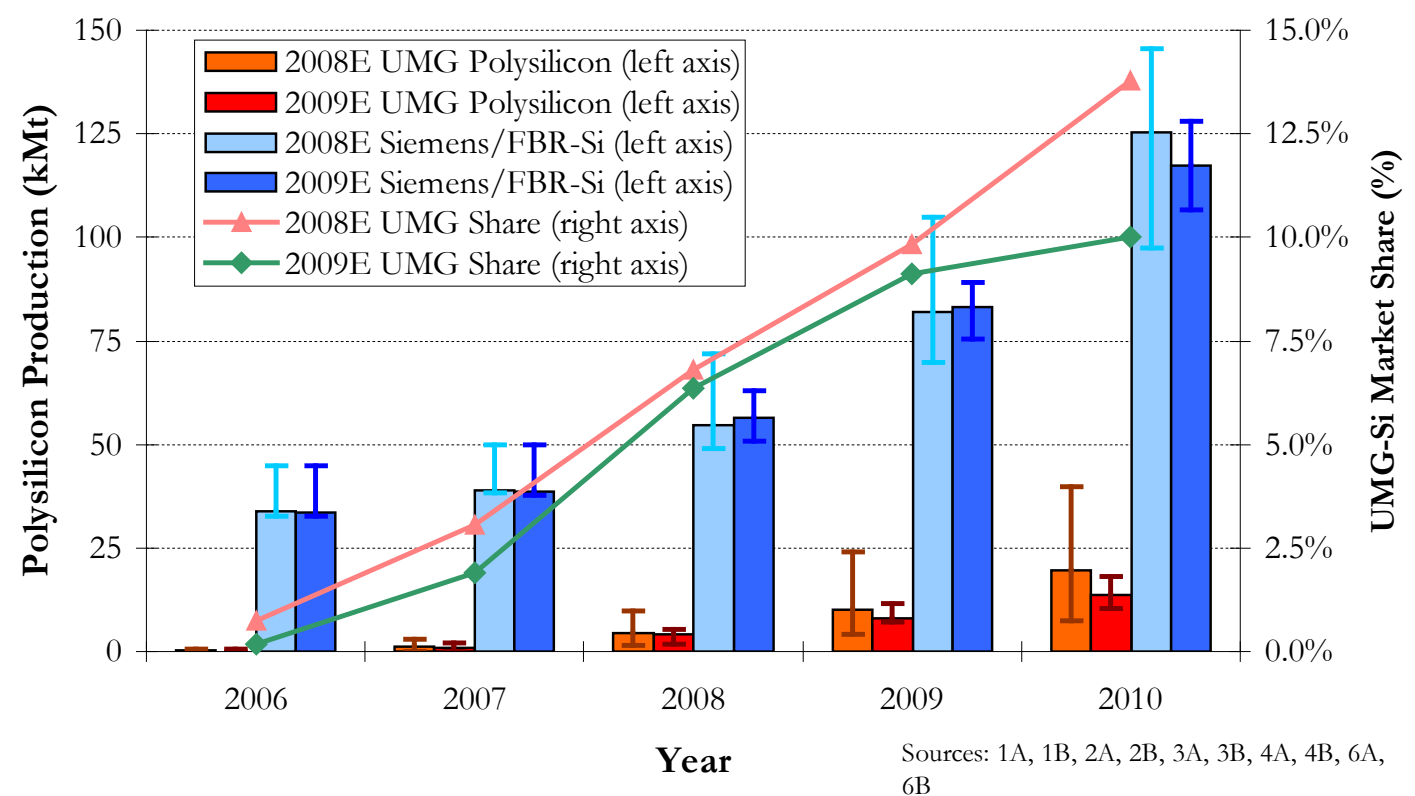

Figure 2. Polysilicon production by technology

Figure 2 shows Q3 2008 and Q1 2009 forecasts for polysilicon production by technology. Siemens and Fluidized Bed Reactor (FBR) technologies are grouped together as both produce polysilicon of industry-standard purity ( $99.999999 \%$, referred to as "six nines"). Upgraded

\footnotetext{
${ }^{9}$ As long as the price of polysilicon exceeds its marginal costs, producers will maintain their operations. However, if prices decline below the marginal costs of higher-cost producers, those manufacturers will be forced out of business and production will decline significantly.

${ }^{10} \mathrm{http}: / / \mathrm{www}$. isuppli.com/NewsDetail.aspx?ID=19683, accessed August 25, 2009.
} 
Metallurgical Silicon (UMG-Si) represents a number of technologies that enhance the purity of metallurgical grade silicon, but not generally to the level of $99.999999 \%$. Figure 2 illustrates that the financial crisis has had similar effects on new versus established polysilicon production technologies as it had on new versus established polysilicon producers. Whereas the median and high 2010 estimates for UMG have declined by $30 \%$ and $54 \%$, respectively, the median and high 2010 Siemens/FBR estimates have fallen only $6 \%$ and $12 \%$. The greater decreases in UMG estimates reflect that it is both a new technology and produced by non-incumbent firms. In addition, as the price of Siemens/FBR polysilicon falls, the cost advantage of UMG-Si, which is less pure and causes diminished module efficiency, declines. More difficult project financing for UMG-based PV installations would further reduce UMG demand. The relatively larger drop in UMG versus Siemens/FBR production estimates is evident as well in the decrease in expected 2010 UMG market share from $14 \%$ to $10 \%$.

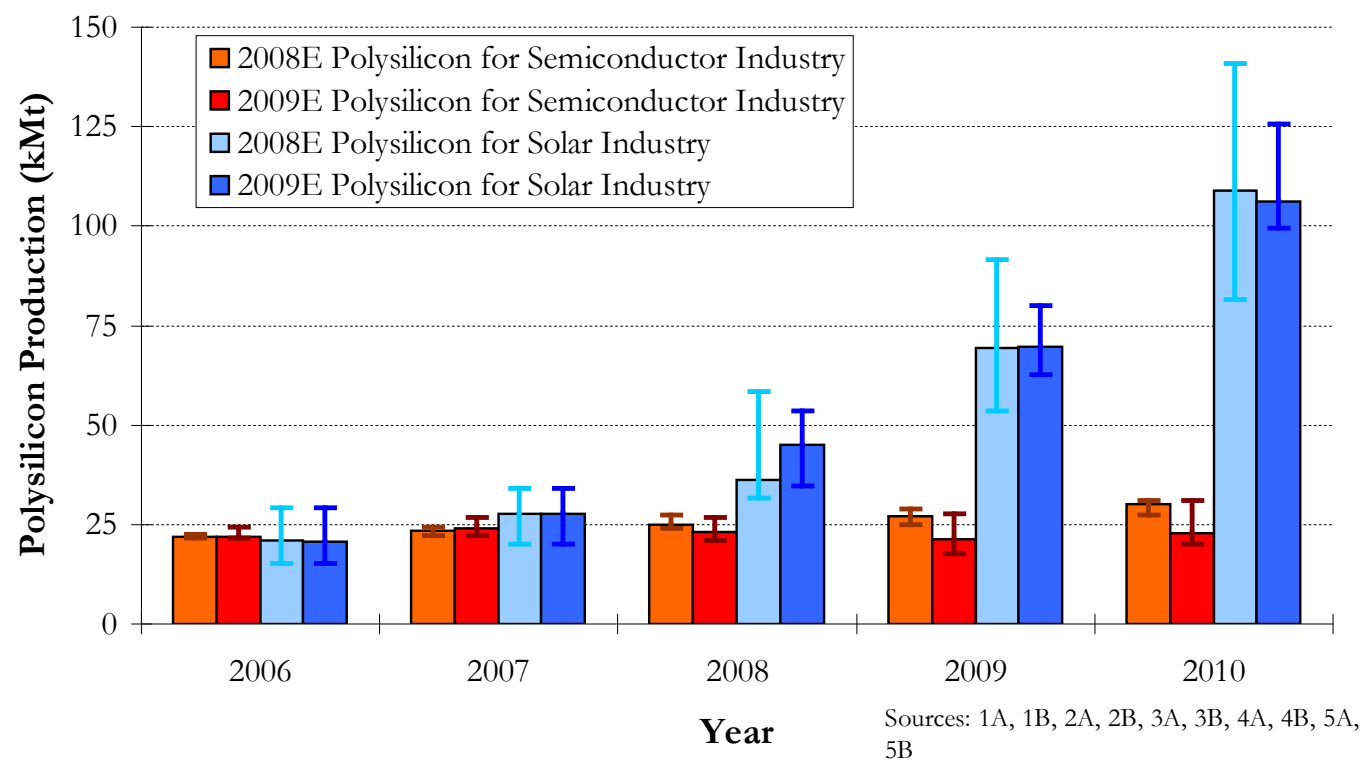

Figure 3. Polysilicon production by end market

After 2006, the solar industry surpassed the semiconductor industry as the largest consumer of high purity silicon feedstock. Figure 3 shows the forecasted continuation of this trend through 2010 and how it has changed between Q3 2008 and Q1 2009. Even with the financial crisis, polysilicon for the solar industry is expected to increase from $45 \mathrm{kMt}$ to $106 \mathrm{kMt}$ between 2008 and 2010 while production for semiconductors remains approximately constant at $23 \mathrm{kMt}$ over that period. Moreover, the median estimates for polysilicon production for the solar industry in 2009 and 2010 are almost unchanged whereas the median estimates for the semiconductor industry dropped by over 20\% in each of those years. Although demand for both semiconductors and PV has decreased as a result of the financial crisis, only polysilicon production for semiconductors reflects the lower end-market demand. This may be the result of demand for polysilicon from the PV industry being more elastic with respect to price than polysilicon demand from the semiconductor industry, as well as the large amount of under-utilized cell and module capacity that can take up excess polysilicon. Under these conditions, excess polysilicon production resulting from lower PV and semiconductor demand would disproportionately go to PV, resulting in a smaller relative decrease for PV polysilicon production. 


\section{PV Module Production Forecasts}

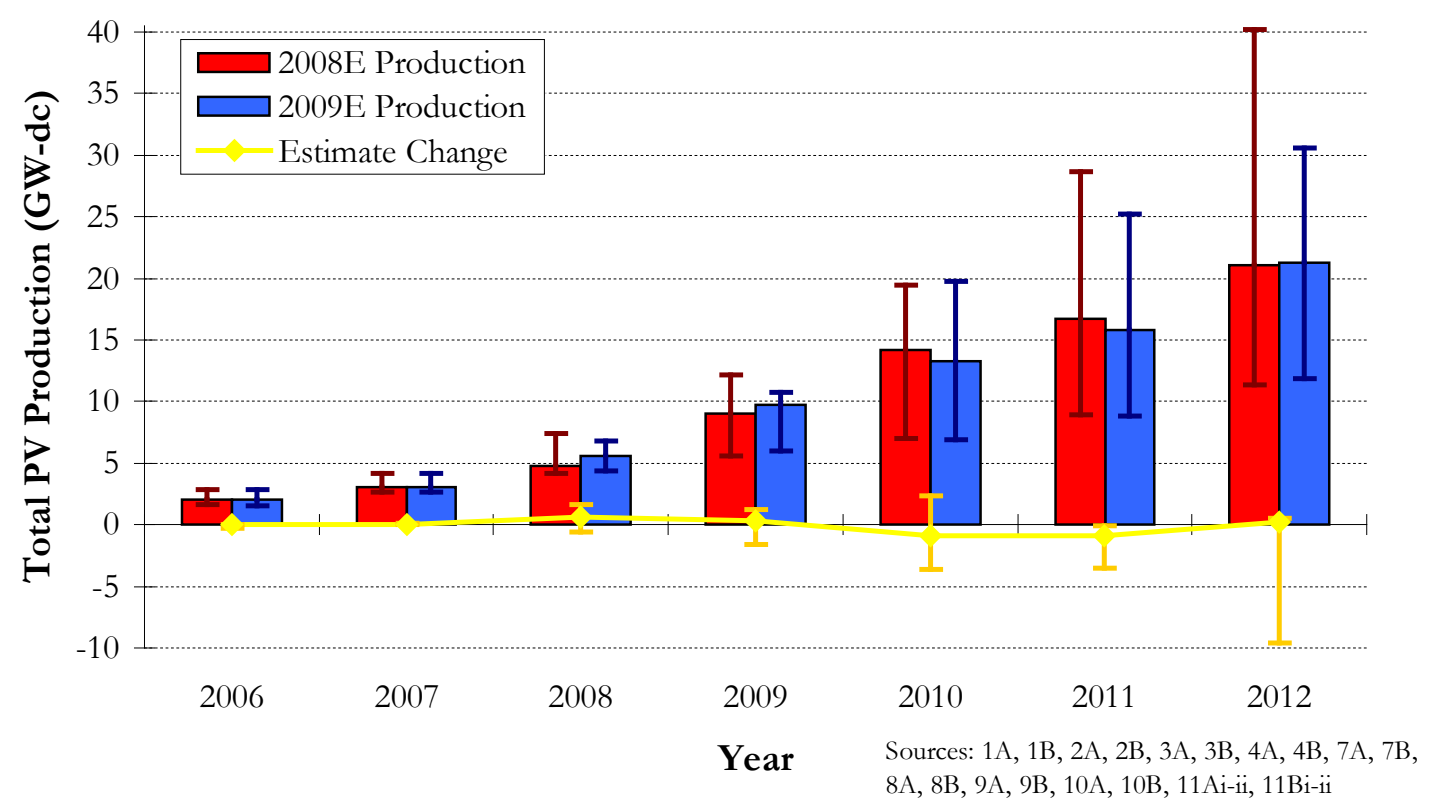

Figure 4. Total PV module production

Figure 4 illustrates forecasted PV module production through 2012 and how those forecasts have changed. As with estimates for polysilicon production, the median projections for PV module production changed only slightly between Q3 2008 and Q1 2009. ${ }^{11}$ Even in the face of the financial crisis, the recent median forecasts are for total module production to increase from $5.6 \mathrm{GW}$ in 2008 to $21.3 \mathrm{GW}$ in 2012, a CAGR of almost $40 \%$. The high estimates, however, decreased significantly in the later years, with the high 2012 estimate declining from over $40 \mathrm{GW}$ to approximately $31 \mathrm{GW}$.

The similar patterns between PV module and polysilicon production forecasts is not surprising given that a large majority of future polysilicon production is for PV modules and that a large majority of PV modules will continue to use polysilicon feedstock. Indeed, most PV module production forecasts are presented in a supply chain model, in which the starting point is total polysilicon production. ${ }^{12}$

However, there are a couple reasons why actual PV module production might be significantly less, at least temporarily, than the amount of polysilicon production would imply. The first is if there are capacity bottlenecks within the supply chain, and module production is limited by wafer, cell or module manufacturing capacity. The second is if lower demand for PV modules results in cell and module producers cutting production. While low marginal costs have resulted, at least so far, in high utilization rates for polysilicon production, this has been less true for cell and module production. In the beginning of 2009, such leading manufacturers as SunPower and Energy

\footnotetext{
${ }^{11}$ Interestingly, the median estimate that changed the most proportionately was that for 2008 , which increased by almost $18 \%$ as the full extent of 2008 production became evident.

${ }^{12}$ We discuss the implications of this production modeling format more fully in Section 3.
} 
Conversion Devices reduced factory production in response to lower demand. ${ }^{13,14}$ In addition to the different cost structures of polysilicon versus PV cell and module producers, cell and module producers with differentiated products, brand awareness or strong balance sheets, such as SunPower, Sanyo, Sharp and Solarworld, have greater pricing power as compared to manufacturers of polysilicon, which is considered more of a pure commodity. ${ }^{15}$

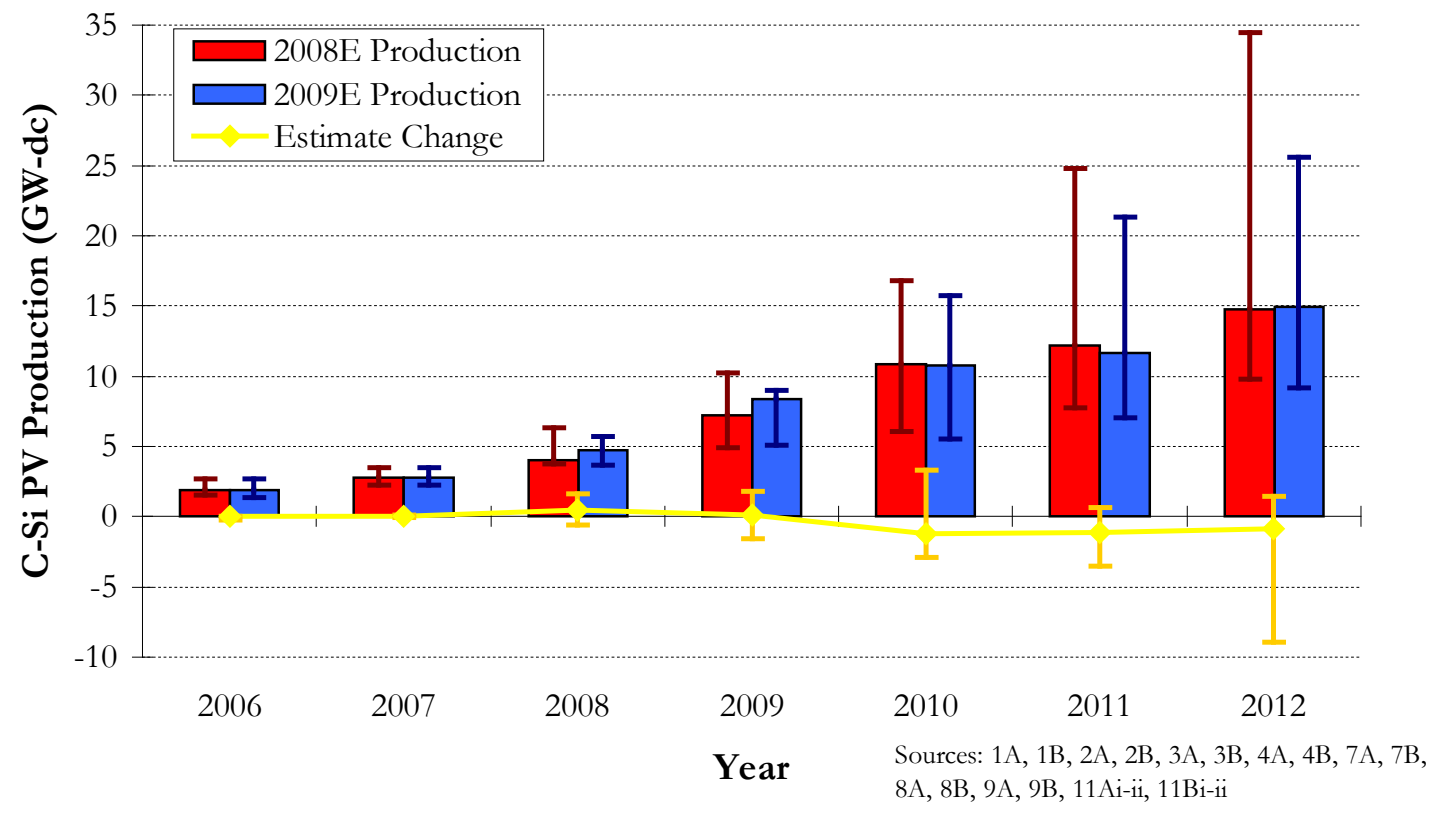

Figure 5. C-Si PV module production

Figure 5 illustrates the projected growth through 2012 of c-Si PV module production. As c$\mathrm{Si}$ is expected to account for a large majority of total PV module production over the next several years, the patterns in Figure 5 are almost identical to those in Figure 4. Specifically, median and low module production estimates are almost unchanged, whereas high estimates for 2011 and 2012 are greatly reduced. Moreover, the Estimate Change line indicates mostly downward revisions in c-Si production forecasts for the later years, as is the case for total module production. However, the recent median c-Si production forecasts reflect a 2008-2012 CAGR of 33\%, somewhat less than the $40 \%$ growth rate for total module production.

\footnotetext{
${ }^{13}$ http://files.shareholder.com/downloads/SPWR/650364744x0xS867773\%2D09\%2D35/867773/filing.pdf, accessed August 25, 2009.

${ }^{14}$ http://files.shareholder.com/downloads/ENER/572209609x0xS32878\%2D09\%2D27/32878/filing.pdf, accessed August 25, 2009.

${ }^{15}$ Moreover, module producers face more regionally-differentiated markets, and thus more regionally-differentiated prices, than do polysilicon producers due to the greater transportation costs for modules.
} 


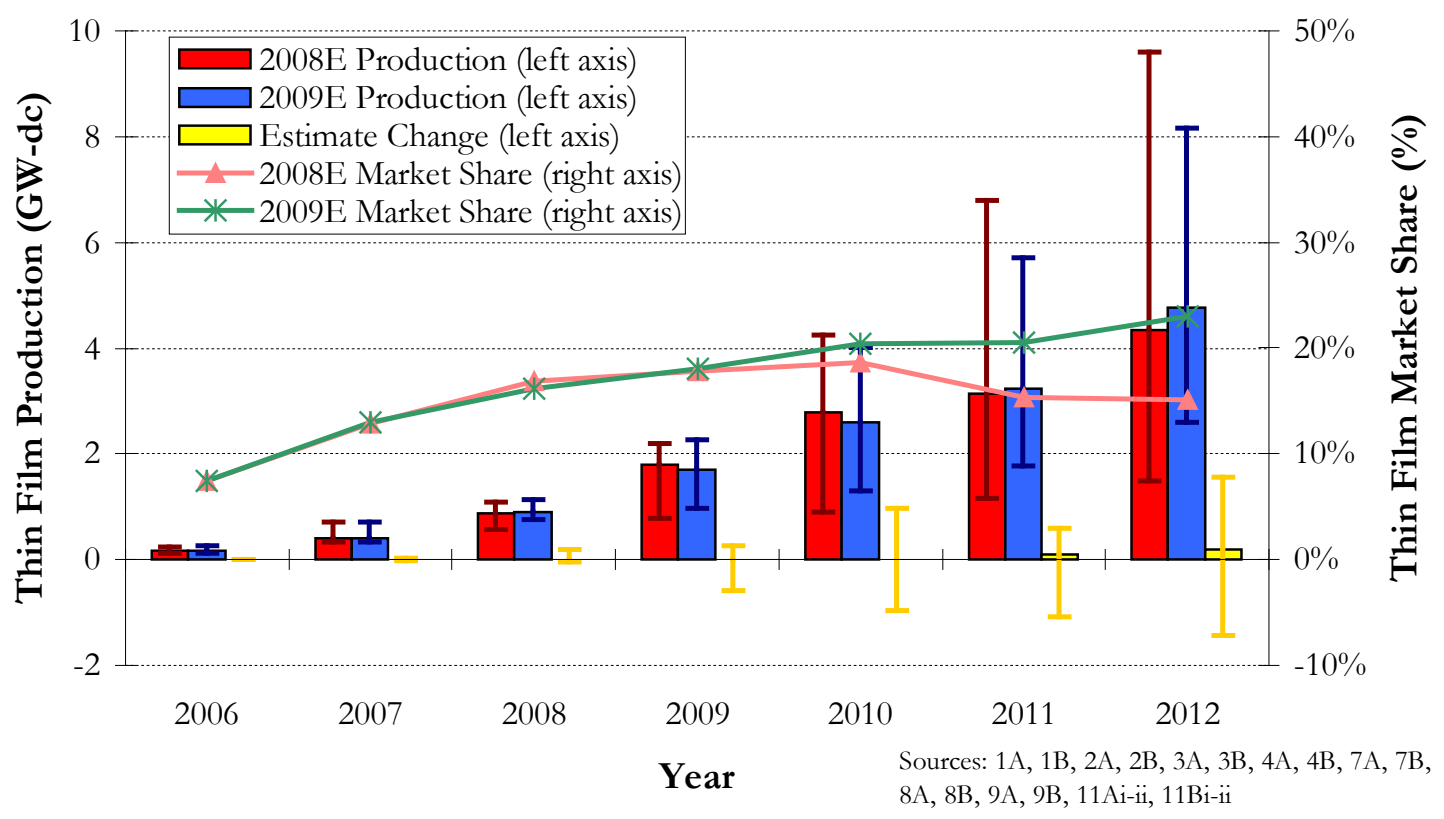

Figure 6. Thin film PV module production

Figure 6, which shows projections for thin film PV production and market share, illustrates the significant differences between expectations for thin film versus c-Si module production and the differential effects of the financial crisis. While Figure 6 shows only modest changes in median thin film production estimates as well as significant reductions in high estimates, as are also evident for c-Si, other patterns are markedly dissimilar for thin film production forecasts.

First, the recent median estimates reflect substantially faster expected growth for thin film compared to c-Si production, with a 2008-2012 CAGR of 52\% versus 33\% for c-Si. Second, for thin film production, estimates were revised significantly upwards as well as downwards. In contrast, cSi production estimates were mostly decreased. The upwardly revised thin film forecasts have resulted in increased low estimates for every year, while the low c-Si production estimates decreased for 2010, 2011 and 2012. Considering these two areas of divergence between thin film and c-Si PV, it is notable that it is a thin film producer, First Solar, which has been among the least affected by the financial crisis in its production expansion. Although First Solar is unique among thin film producers, it accounts for a substantial fraction of thin film production. Moreover, given the number of promising thin film startups which received substantial funding in 2007 and 2008, there is a good chance of other thin film companies achieving scale within the next several years.

Even with increased low estimates and decreased high estimates narrowing the range of forecasts for thin film production, the range remains greater for thin film versus c-Si production forecasts. The greater uncertainty for thin film PV is sensible given that thin film faces technology and scale-up risks, which are less significant for the more mature crystalline silicon technology. However, the median forecasts for thin film market share suggest that thin film PV will overcome these obstacles. Not only did the median thin film market share estimates increase between Q3 2008 and Q1 2009, but the recent estimates show consistent growth in thin film market share, whereas the old estimates have thin film market share peaking in 2010 and declining thereafter. 


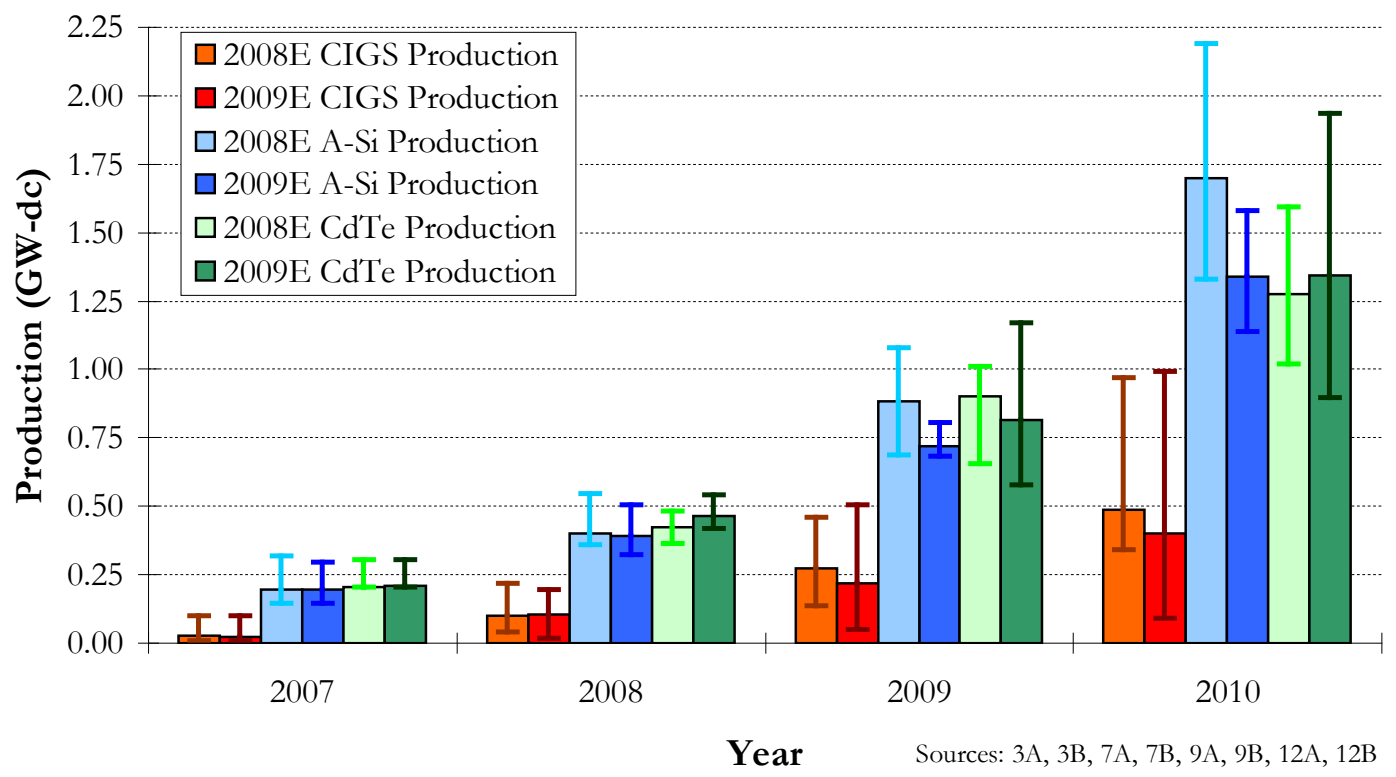

Figure 7. Thin film PV module production by technology

Despite having projections from only four analysts and only through 2010, the forecasts of thin film module production by technology in Figure 7 yield several interesting insights. Most noticeable is the degree of uncertainty of production for each of the technologies, even though the projections go no further than two years into the future. Notwithstanding the considerable uncertainty, there is tremendous growth implied by the recent median estimates, with 2008-2010 CAGRs of 70\%, 85\% and 96\% for Cadmium Telluride (CdTe), amorphous Silicon (a-Si) and Copper Indium Gallium (di)Selenide (CIGS) production, respectively.

For CdTe, it is surprising that there is so much uncertainty in the estimates for 2009 and 2010 production, and that the uncertainty increased between Q3 2008 and Q1 2009, given that First Solar has delivered such consistent results. First Solar accounts for virtually all of $2008 \mathrm{CdTe}$ production of roughly $500 \mathrm{MW}$, and the company plans to have over $1 \mathrm{GW}$ of total manufacturing capacity by the end of 2009. The sizeable range may be the result of divergent opinions regarding the prospects of new CdTe entrants, such as PrimeStar Solar and Abound Solar, as well as skepticism regarding the pace of First Solar's expansion. Nonetheless, it should be noted that CdTe was the only thin film technology for which either the median or high 2010 production estimate increased meaningfully.

For a-Si, there are both established producers, such as Energy Conversion Devices, Sharp and Kaneka, as well as numerous entrants, many of which have planned to enter the market through the purchase of turnkey systems from Applied Materials or Oerlikon. However, given the capital expenditures necessary for the purchase of turnkey production lines, expansion of a-Si production from entrants has been curtailed by the tight credit environment. In addition, as PV module prices have fallen faster than non-module prices over the past year, non-module prices have risen as a proportion of total system prices. Since non-module prices per Watt rise as module efficiency declines, a-Si, which has the lowest efficiency of any of the principal PV technologies, has become 
less attractive. ${ }^{16}$ It is noteworthy that the median 2010 estimate for a-Si production experienced the greatest absolute and proportional reduction of the thin film technologies.

CIGS module production is starting from a very low base, a median 2008 estimate of just 104 MW, but is expected to grow substantially in the near term. The median projection for 2010 is 400 MW, with low and high estimates of around $100 \mathrm{MW}$ and $1000 \mathrm{MW}$, respectively. The enormous range reflects both the substantial scale-up and technology risks, as companies such as Miasole, Nanosolar and Solyndra expand commercial production, and also the promise of the technology, which has the potential for similar costs but higher efficiencies than CdTe or a-Si modules. The median 2010 estimate decreased by $18 \%$ and the low estimate by $74 \%$, perhaps reflecting that technology and scale-up risks become greater hurdles in a credit-constrained environment.

\section{PV Module Demand Forecasts}

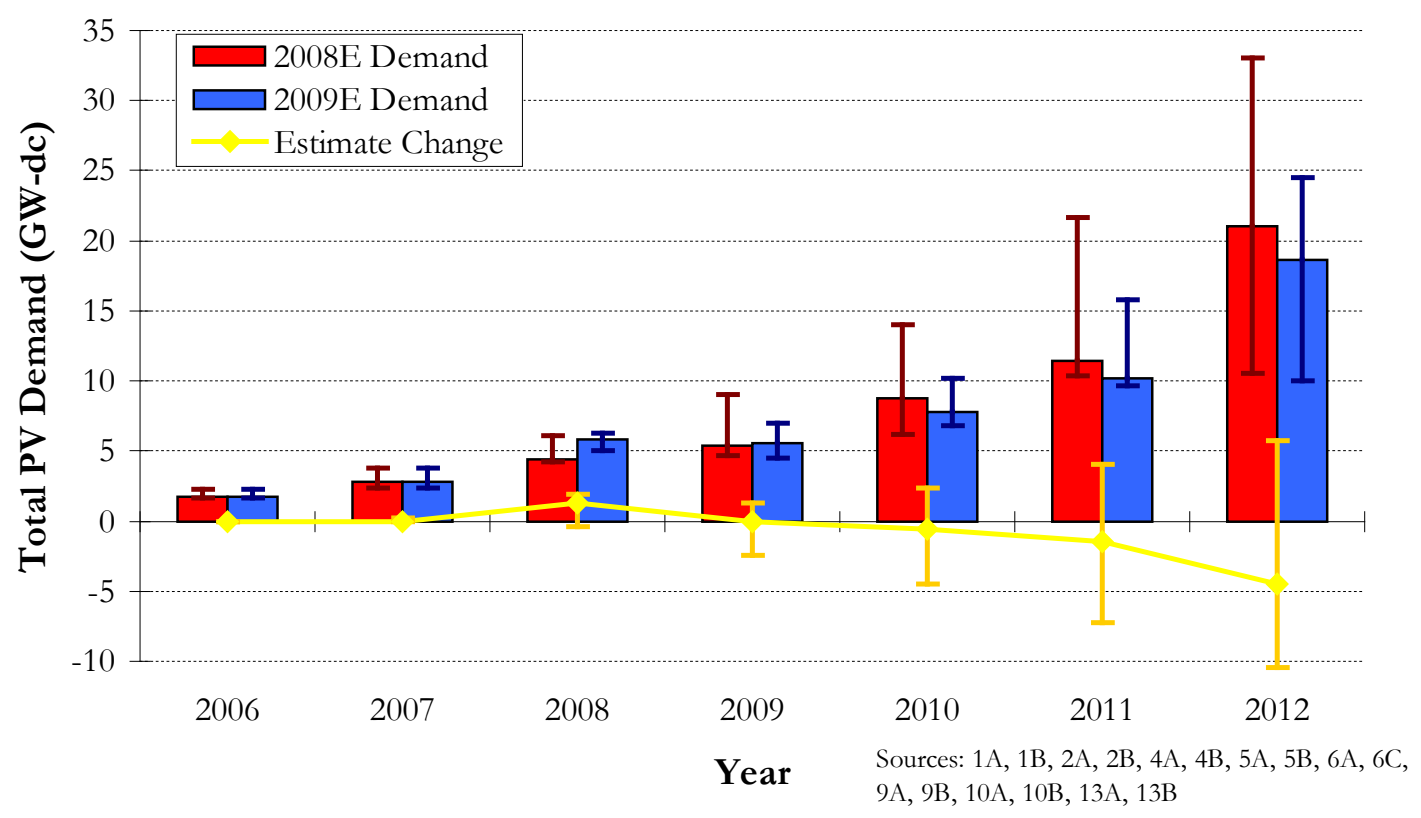

Figure 8. Global PV module demand

Figure 8 displays the forecasts for global PV module demand and how these estimates have changed from Q3 2008 to Q1 2009. The recent median estimates still indicate rapid growth, with demand increasing from $5.8 \mathrm{GW}$ in 2008 to $18.7 \mathrm{GW}$ in 2012, a four-year CAGR of 34\%. However, the previous median demand estimates for 2008 to 2012 grew at a CAGR of $48 \%$, with the decline in the projected growth rate due to a lower 2012 projection and a higher 2008 estimate. The upwardlyrevised estimate for 2008 demand is also responsible for the forecasted drop in demand between 2008 and 2009.

\footnotetext{
${ }^{16}$ In addition, with the growth of utility-scale markets, the greater use of trackers has raised the value of higherefficiency modules.
} 
Comparing Figure 8 to Figure 4, which shows PV production forecasts, suggests both similarities and differences in the effects of the financial crisis on demand versus production. The pattern of the high and low estimates for production and demand is very similar, with high estimates reduced considerably and low estimates nearly unchanged. However, the median estimates for 2010-2012 demand have declined more significantly and consistently than those for production, a trend also reflected in larger downward median revisions in estimates for demand versus production.

The greater change in demand estimates could indicate that demand for PV modules is more immediately sensitive to changes in financing costs and availability than is PV module production. PV module production is financed substantially by venture capital, private equity and public equity investments and spent over several years. Additionally, more mature module producers may fund expansions, in part or total, using operating income. In contrast, project finance debt (and tax equity in the case of the U.S.) must be raised continuously for the installation of new PV systems, and cash flow from operations is not generally a viable option for significant financing. More expensive financing may thus have a more immediate impact on PV module demand than on module production.

While the decline in fossil fuel prices over the past year would also lead to a reduction in PV demand, this effect is likely to be less significant than that of constrained and more expensive financing. In many large markets for PV, such as Germany, the feed-in-tariffs are based on the cost of renewable energy projects. They are not based on current electricity prices, and thus the return on an investment in PV is independent of fossil fuel prices. Even in markets where this is not the case, prices of electricity, as an often-regulated commodity, may be somewhat insensitive to fossil fuel prices.

Finally, the net direction of other indirect effects of the financial crisis on PV demand is unclear. Lower wealth and income would reduce aggregate electricity demand as well as consumers' willingness-to-pay for the non-market environmental attributes of PV, but expansionary fiscal policies aimed at increasing the deployment of renewable energy (provided that governments have the available funds) would act in the opposite direction. 


\section{Regional PV Module Demand Forecasts}

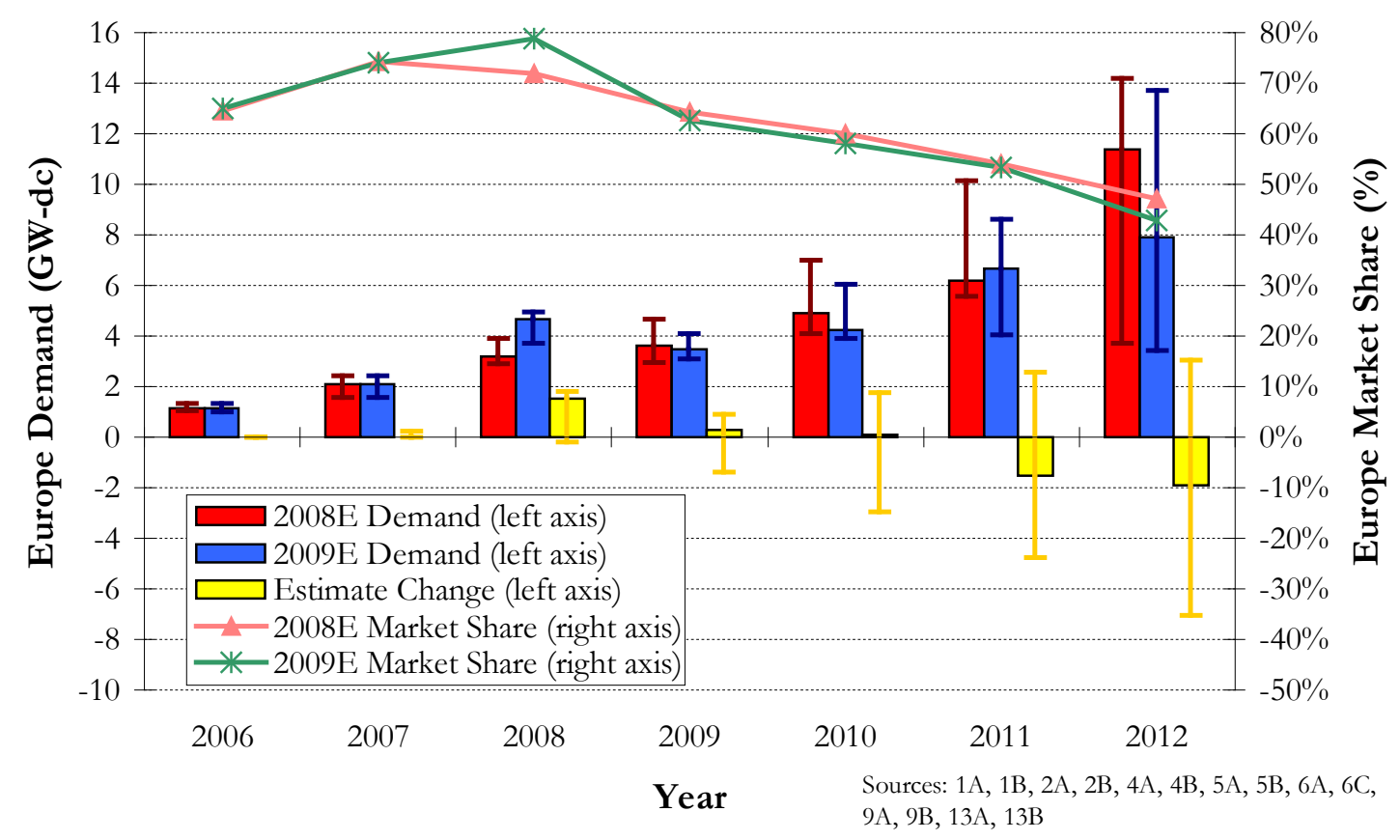

Figure 9. Europe PV module demand ${ }^{17}$

Figure 9 shows the forecasts and estimate changes for PV module demand in Europe as well as Europe's share of the global PV market. The most recent median forecasts are that European PV demand will increase from $4.7 \mathrm{GW}$ in 2008 to $7.9 \mathrm{GW}$ in 2012, a CAGR of $14 \%$. A striking feature of Figure 9 is the large upward revision for estimated 2008 demand, due to far greater capacity installed in Spain than was previously anticipated, which partially accounts for a projected growth rate far below that of the global market. However, it is also the case that in 2010-2012, growth of the more mature European market is not expected to keep pace with that of the developing U.S. and Asian markets. This trend is reflected in European market share, which reached almost $80 \%$ in 2008 but is expected to decline to $43 \%$ in 2012 .

Between Q3 2008 and Q1 2009, estimates for future European demand were mostly revised downwards, albeit with considerable variation in the estimate changes. Despite a capped Spanish market and a relatively stable German market, the uncertainty of European demand remains very large, with the high 2012 estimate over four times the value of the low 2012 estimate. The broad range reflects divergent views on the near-term prospects for emerging European markets, principally Italy, France and Greece. While the feed-in tariffs are favorable in these countries, there may be bureaucratic and other factors that inhibit the growth of PV. ${ }^{18}$ Lastly, it is notable that the

\footnotetext{
${ }^{17}$ 2008E Demand was aggregated from forecasts made after indications in late Q2 2008 that the Spanish government would place a cap on PV installations eligible for its feed-in tariff, eventually set at 500MW. This had a large impact on European and global PV demand, as Spain installed over 2 GW of PV in 2008. Market share estimates represent the median forecasts from Q3 2008 and Q1 2009, respectively.

${ }^{18}$ For example, in France the feed-in tariff structure favors building-integrated photovoltaics (BIPV), currently a small sub-sector of the PV industry.
} 
median market share estimates for 2009 through 2012 did not change significantly between Q3 2008 and Q1 2009. While this is partially due to Europe's large share of the global market, it also reflects the analysts' judgment that the impact of the financial crisis on the European market is roughly in line with the crisis' impact on the global market. ${ }^{19}$

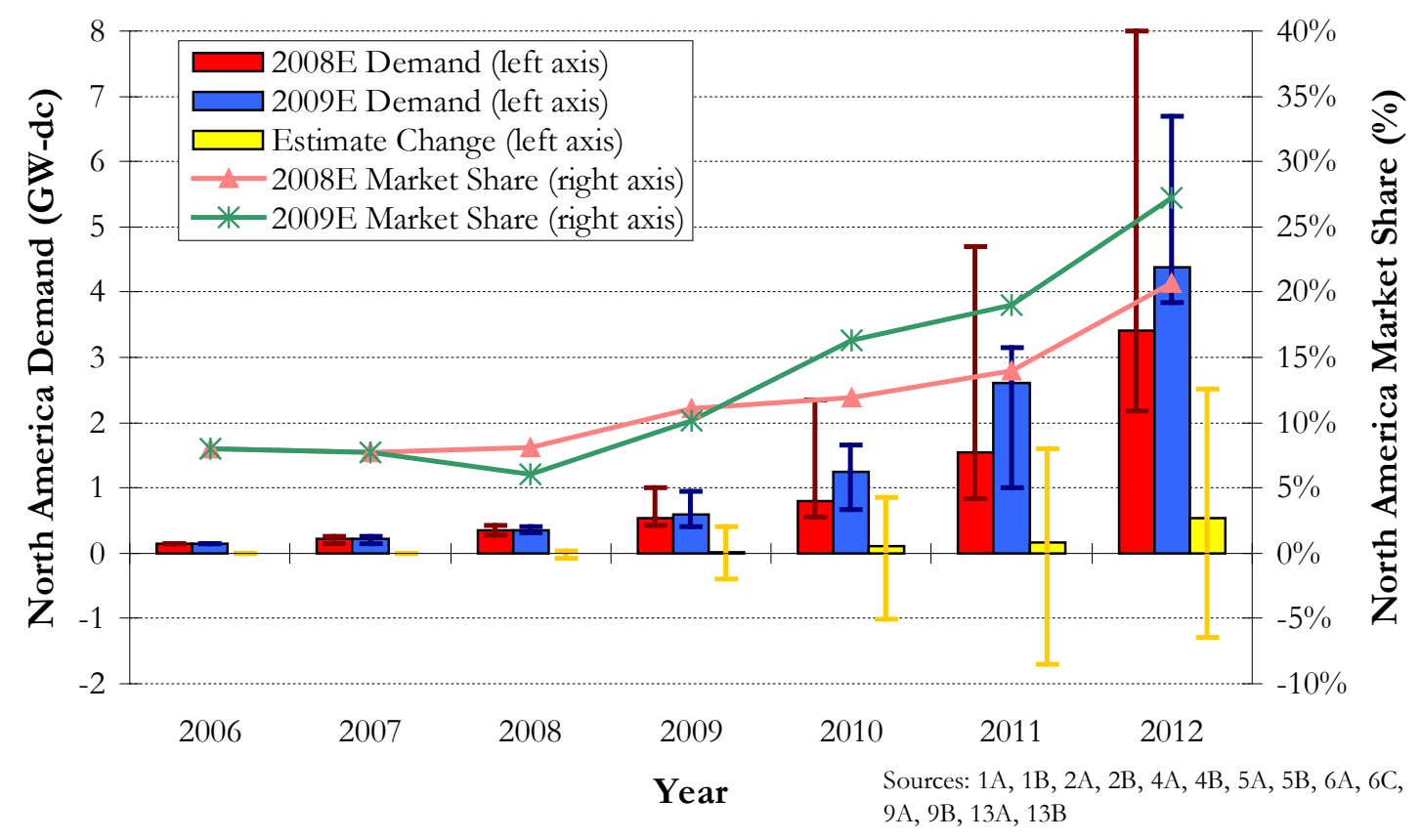

Figure 10. North America PV module demand ${ }^{20}$

Figure 10 illustrates the projections and estimate changes for North American PV demand and forecasts for North America's market share. Although the United States accounts for a large majority of North American demand through 2012 in these estimates, analysts also expect Canada to contribute meaningfully, particularly as a result of Ontario's enhanced feed-in tariff. The median Q1 2009 projections are for North American PV demand to increase from less than $400 \mathrm{MW}$ in 2008 to almost $4.4 \mathrm{GW}$ in 2012, a CAGR of $87 \%$, making the region by far the fastest growing market for $\mathrm{PV}$. This is also reflected in the rising projected market share for North America, growing from $6 \%$ in 2008 to $27 \%$ in 2012. While the increasing North American demand and market share are not surprising given its currently small market size, high-quality solar resource for much of the region's population and large potential market, the expected rate of absolute and market share growth is striking.

Between Q3 2008 and Q1 2009, almost all measures indicated improved expectations for the North American PV market. ${ }^{21}$ For 2010, 2011 and 2012, the median forecasts for demand and

\footnotetext{
${ }^{19}$ Even as Europe's share of the global market decreases from 2009 to 2012, the change between 2008E Market Share and 2009E Market Share for each year from 2009 to 2012 remains small.

${ }^{20}$ North America includes the United States and Canada for analysts that make projections by country rather than by region. Mexico and other North American countries are not expected to contribute substantially to PV demand in the near term.
} 
market share increased and the median estimate change was positive. Although the high demand estimates did indeed decline, the low estimates rose, and in the case of 2012, the low estimate increased by over $75 \%$. Consequently, the range for 2012 North American demand estimates has narrowed considerably and now reveals far less uncertainty than that which exists for the European market. The contrast between increased estimates for North American demand and decreased estimates for European demand between Q3 2008 and Q1 2009 reflects differences in policy changes and expectations in the two regions during that time period. Whereas the solar policy environment in Europe was comparatively stable at the end of 2008 and beginning of 2009, in the United States there was a new President, the passing of an economic stimulus bill that emphasized the deployment of renewable energy and the prospects of Federal legislation on climate and a national Renewable Electricity Standard. In addition, the Canadian province of Ontario proposed a more generous feedin tariff in March 2009. ${ }^{22}$

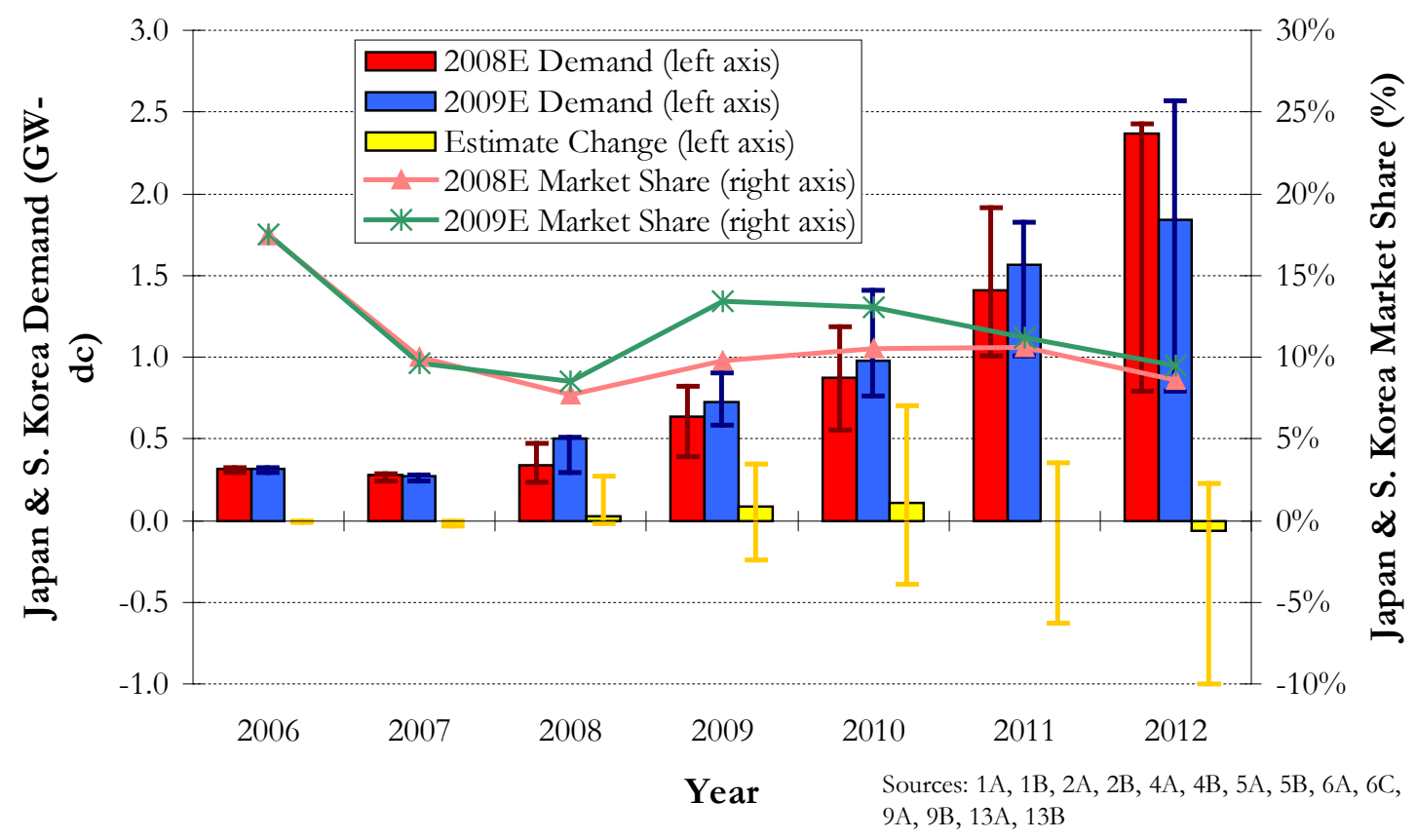

Figure 11. Japan and South Korea PV module demand ${ }^{23}$

Figure 11 shows the forecasts for demand and market share and changes in demand estimates with respect to the combined markets of Japan and South Korea. Japan had the largest installed capacity of PV from 1997 until 2005, when it was overtaken by Germany. South Korea's market development has occurred more recently, with the establishment of a feed-in tariff in 2006 to help the country reach its mandate of 5\% of electricity generated from renewables by 2011 . The combined markets are expected to grow from $500 \mathrm{MW}$ in 2008 to over $1.8 \mathrm{GW}$ in 2012, a CAGR of

\footnotetext{
${ }^{21}$ While some of the Q3 2008 estimates were made prior to the extension of the U.S. investment tax credit (ITC), this does not appear to have exerted downward pressure on those estimates.

22 http://www.thestar.com/Business/article/604650, accessed August 25, 2009.

${ }^{23}$ While other Asian markets, such as China and India, have great potential for PV, only Japan and South Korea to date have installed PV capacity greater than 100 MW. Moreover, Japan and South Korea are set apart from other Asian markets by their current state of economic development.
} 
$39 \%$. While Japan and South Korea's combined market share is expected to increase in 2009, assisted by the decline in European demand, it is projected to gradually decrease thereafter as markets in North America and the rest of the world grow more rapidly.

The changes in estimates from Q3 2008 to Q1 2009 are more mixed for the Japanese and South Korean market than for those of Europe or North America. Although the adjustments were generally positive for 2009 and 2010, they turned mixed thereafter. The positive changes for 2009 and 2010 likely reflect the decision made by the Japanese government in December 2008 to reinstate subsidies for residential PV starting in January 2009, which had been withdrawn in 2005. For South Korea, many of the Q3 2008 estimates account for the October 2008 reduction in the country's feedin tariff. Increased estimates made in Q1 2009 could be the result of greater visibility into South Korean demand several months after the incentive reduction occurred.

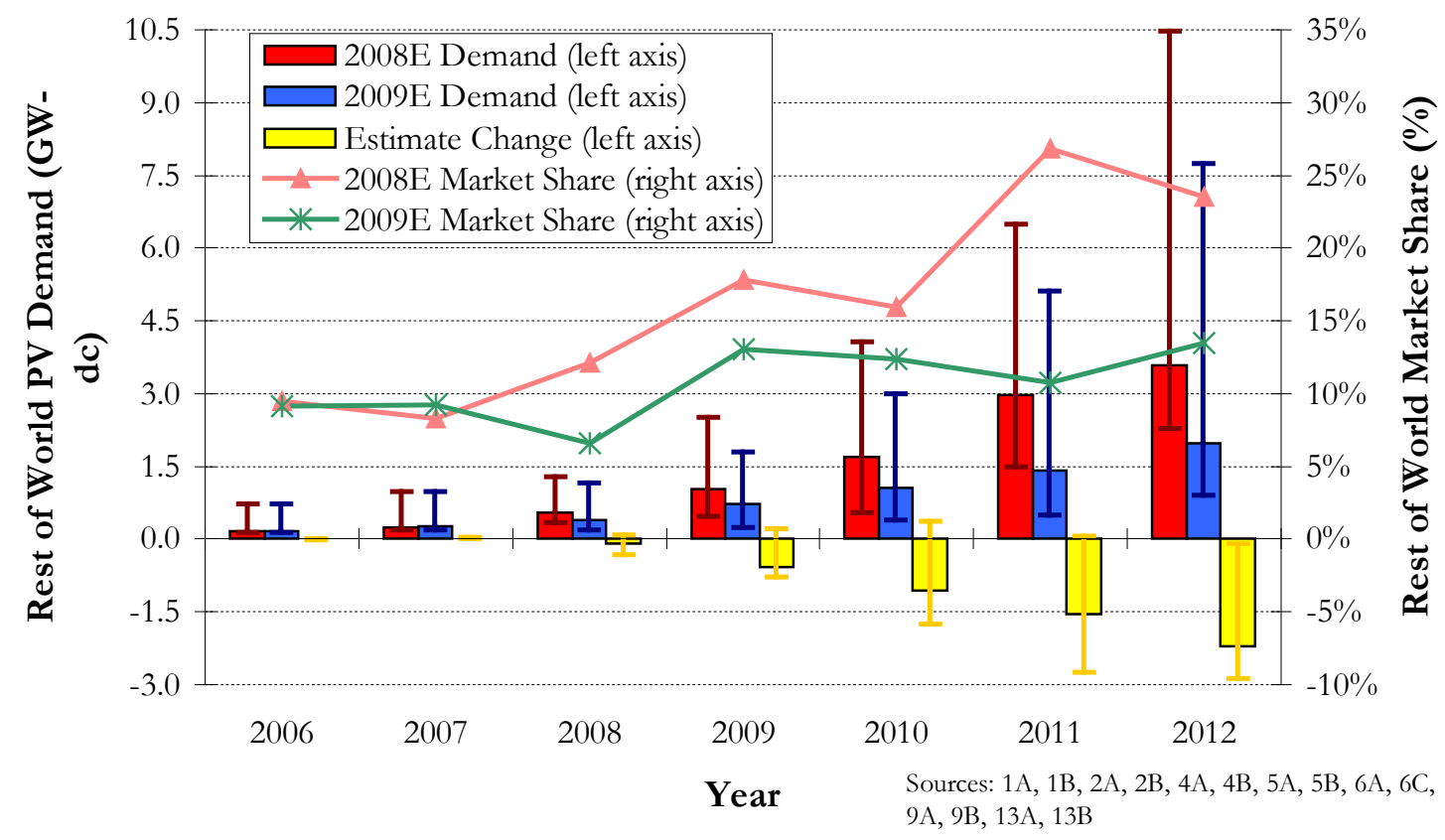

Figure 12. Rest of world PV module demand ${ }^{24}$

Figure 12 illustrates the demand and market share forecasts, as well as the demand estimate changes, for the rest of the world (ROW), which includes China, India, Australia, the Middle East and other emerging markets for PV. The recent median estimates envisage that ROW PV demand will increase from $390 \mathrm{MW}$ in 2008 to almost $2 \mathrm{GW}$ in 2012, a CAGR of $50 \%$. As a result, the market share of ROW is expected to rise from $6.6 \%$ in 2008 to $13.5 \%$ in 2012 . However, the uncertainty around these median estimates is vast. For 2012, the high demand estimate is over eight times the value of the low demand estimate, reflecting both the great potential but also the nascent state of these markets.

\footnotetext{
${ }^{24}$ It should be noted that the Q1 2009 estimates were all made prior to the June 2009 disclosure of India's solar targets and that almost all of the estimates occurred before the announcement in late March 2009 of China's first PV subsidy program, aimed at BIPV. Since March, China has announced an additional subsidy program for larger systems, and Chinese producers have signed letters of intent totaling GWs of installed PV capacity.
} 
Between Q3 2008 and Q1 2009, the forecasts for ROW demand and market share declined almost universally. Low, median and high demand forecasts from 2009 to 2012 dropped, as did median market share estimates. Moreover, the Estimate Change bars reveal that analysts unanimously lowered their 2012 demand forecasts. That the financial crisis would have disproportionately adverse affects on ROW is reasonable, as projects in emerging markets generally entail greater financial risk and are more vulnerable to an environment of tightened credit. ${ }^{25}$

\section{Market Equilibrium Forecasts}

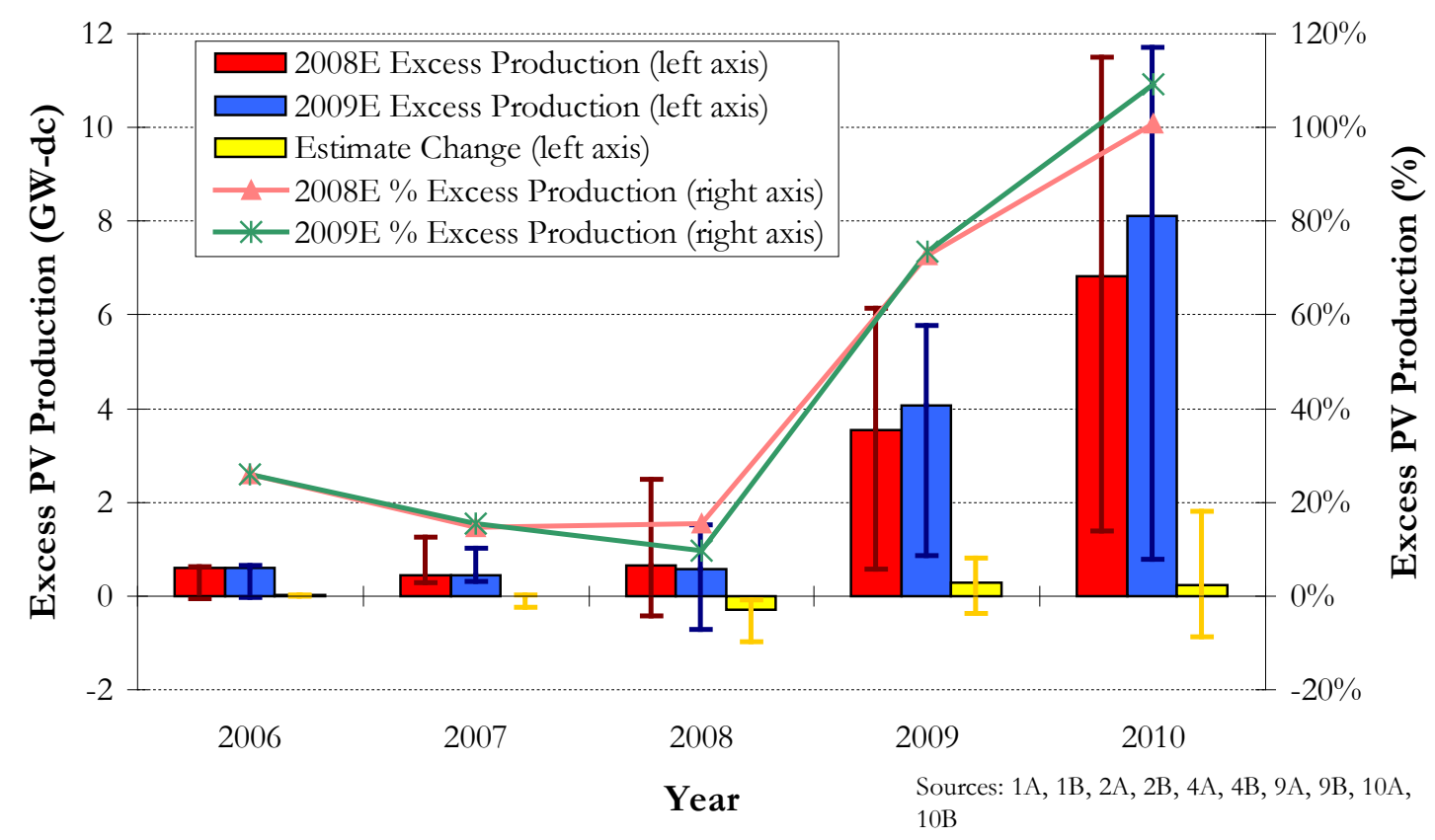

Figure 13. PV Module production versus demand ${ }^{26}$

Figure 13 shows the absolute and relative differences between forecasted PV module production and demand through 2010. ${ }^{27}$ Production and demand projections are often made with separate bottom-up models, in which case estimated future years' production and demand will not necessarily be equal. ${ }^{28}$ For PV module production, the starting point of bottom-up supply chain models is usually total polysilicon production, aggregated across incumbent and new producers. Polysilicon for solar is calculated by subtracting semiconductor polysilicon demand and adding back recycled material, and c-Si PV production is reached with assumptions about average grams of silicon per Watt, a cell-to-module conversion factor and inventory fluctuations in the supply chain prior to module assembly. Adding thin film PV production, based on planned expansions of existing producers and entry of new firms, yields total PV production. For PV demand, analysts generally

\footnotetext{
${ }^{25}$ However, there are exceptions to this. For example, the credit environment in 2009 has been more favorable in China than in the U.S. or Europe given the better-capitalized condition of China's banking system.

${ }^{26}$ Only includes forecasts from analysts who have provided both production and demand estimates.

${ }^{27}$ Relative excess production equals (PV production - PV demand) / PV demand

${ }^{28}$ Actually, production should be somewhat greater than demand to maintain a stable proportion of module inventory as the industry grows.
} 
consider the available incentives, solar resource and electricity prices, by state, country or region, to determine the rate of return on investment in PV, from which they estimate demand.

The key missing short-term variables are price and capacity utilization, which are implicitly fixed in production and demand models, but will adjust in the real world so that supply/demand equilibrium is reached. It is nonetheless useful to examine the trends in projected excess production as they elucidate price projections, discussed in the next sections. ${ }^{29}$ As illustrated in Figure 13, recent median estimates for absolute and relative excess production increase dramatically from 2008 to 2009 and 2010. For 2008, the median estimate for excess production was less than $10 \%$ and the low estimate was negative, implying that module inventory decreased in order to meet demand. However, for 2009 and 2010, the recent median estimates for excess production increase to $74 \%$ and $109 \%$, respectively, as production expansion outpaces demand growth. Moreover, between Q3 2008 and Q1 2009, median estimates of 2009 and 2010 absolute and relative excess production have increased due to the greater adverse effect of the financial crisis on demand than on production.

This is not to suggest that analysts expect actual 2010 production to be over twice the level of annual demand. ${ }^{30}$ Excess production will lead to a decline module prices, which will raise the quantity of modules demanded, and the prospect of lower prices will lead some firms to cut production (lower their capacity utilization) and other firms to cease production entirely. As previously noted, in early 2009, such leading PV module producers as SunPower and Energy Conversion Devices announced work furloughs or idling of manufacturing lines in response to lower demand.

\footnotetext{
${ }^{29}$ It is difficult to compare the magnitude of different analysts' projections of future excess production, as the price and utilization assumptions used in their models may differ. For instance, an analyst with a lower estimated excess production may be assuming a greater price reduction and/or lower capacity utilization than an analyst with a higher estimated value. The low estimates for 2009 and 2010 are likely examples of forecasts with such assumptions.

${ }^{30}$ It is also important to distinguish projected production from projected capacity, which forms the upper bound for future production. Production estimates assume a certain capacity utilization, which will result in divergence between projected production and capacity as utilization declines below 100\%.
} 


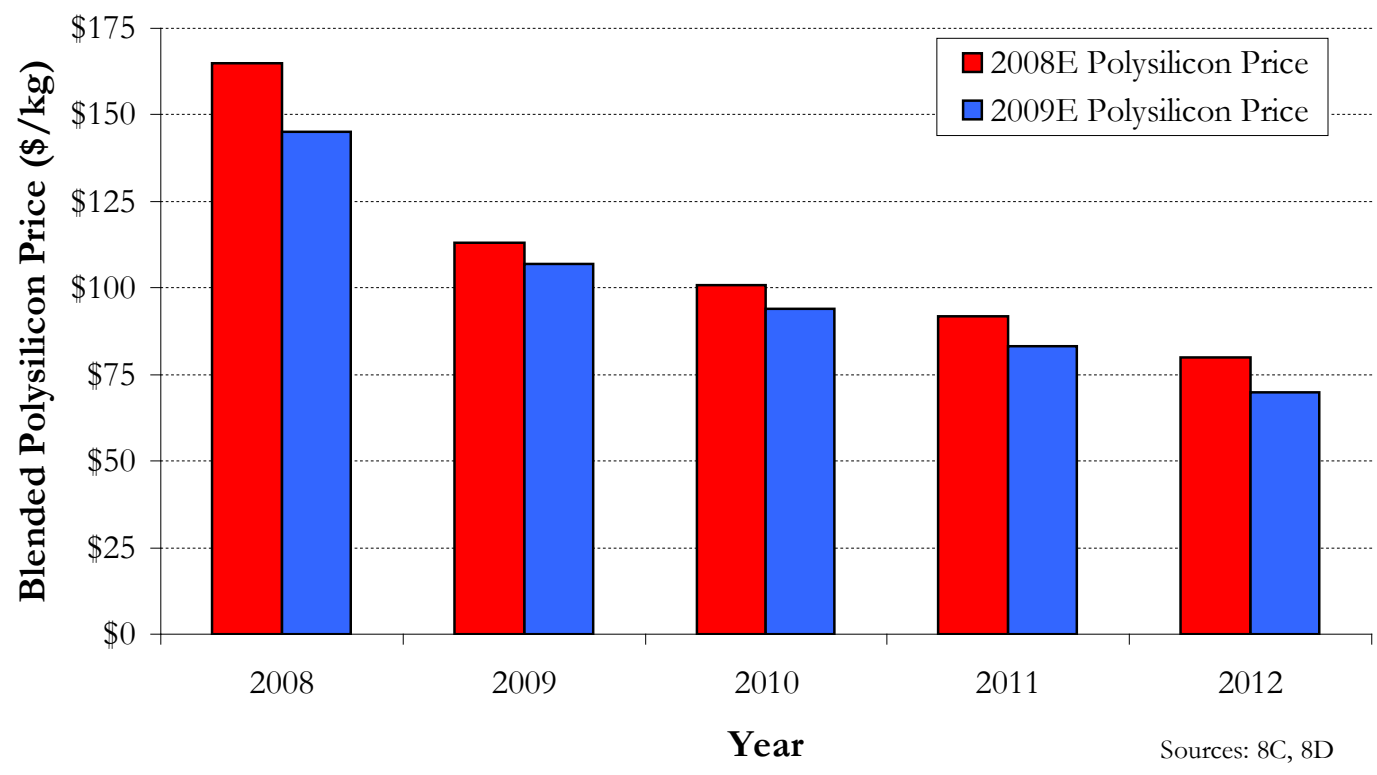

Figure 14. Blended polysilicon prices ${ }^{31,32}$

Figure 14 shows forward contract prices for polysilicon, as surveyed at the end of 2008 and the beginning of 2009. Even as estimated in the late 2008 survey, future prices for polysilicon declined rapidly over time, from $\$ 165 / \mathrm{kg}$ in 2008 to $\$ 80 / \mathrm{kg}$ in 2012 . Polysilicon prices peaked in early 2008 , with prices on the spot market as high as $\$ 500 / \mathrm{kg}$, as production capacity had lagged rising demand from the PV industry. However, with expected production capacity expansions, which were often started years earlier, outpacing polysilicon demand in 2009 and afterwards, future contract prices declined substantially and persistently in the years after 2008. The financial crisis intensified this trend by diminishing polysilicon demand, reflected in the drop in forward prices of roughly $10 \%$ for each year between the late 2008 and early 2009 surveys.

\footnotetext{
${ }^{31}$ There were not a sufficient number of estimates of spot, long-term contract or, ideally, volume-weighted averages of spot and long-term contract prices to aggregate and analyze polysilicon price forecasts. However, given the importance of polysilicon prices to c-Si module costs, we show data from the New Energy Finance Silicon Price Index from December 2008 and March 2009. The data represents volume-weighted averages of prices of polysilicon forward contracts for delivery in each year from 2008 to 2012. As such, the prices listed for 2008 are below those of the spot market, which rose as high as $\$ 500 / \mathrm{kg}$, and above long-term contract prices, which were less than $\$ 100 / \mathrm{kg}$.

${ }^{32}$ In 2008 or 2009 dollars depending on the year of the survey.
} 


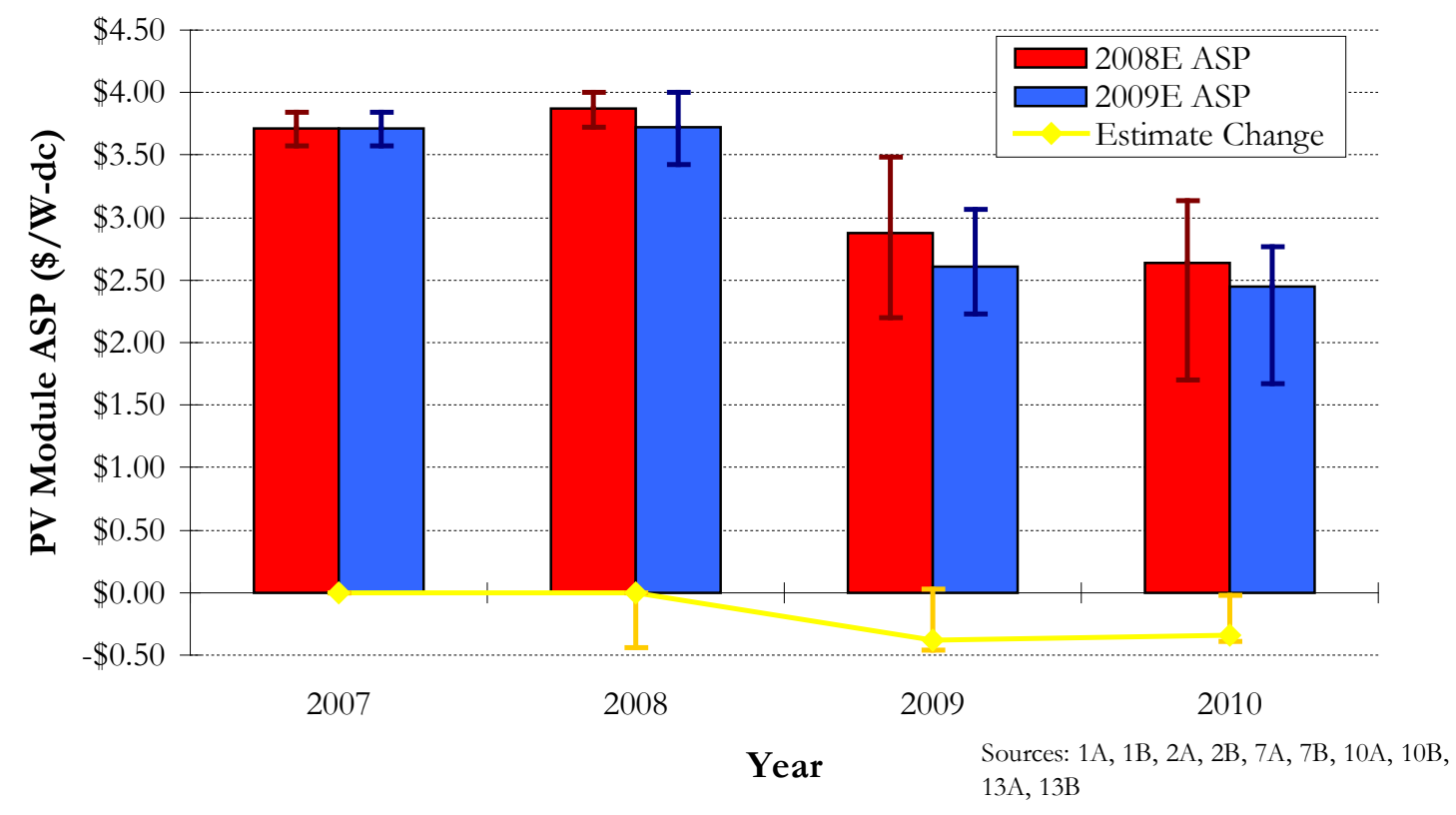

Figure 15. Average PV module prices ${ }^{33}$

Figure 15 shows the forecasted average module prices and estimate changes through 2010 . The recent median projections are that module prices will decrease from $\$ 3.72 /$ Watt in 2008 to $\$ 2.45 /$ Watt in 2010, a CAGR of $-19 \%$. The trend is similar to that forecasted in Q3 2008, in which module prices were expected to decline at a CAGR of $-17 \%$. Even prior to the financial crisis, it was apparent that the increasing production capacity across the PV supply chain would lead to lower future module prices. Moreover, the subsidies in such large PV markets in Germany decline each year, and thus module prices must decline for developers' margins and investors' returns to remain constant.

Although the 2008-2010 trend did not change significantly between Q3 2008 and Q1 2009 projections, there was a downward shift in the median estimates for each year. This adjustment of expectations is also revealed in the Estimate Change bars, which are almost uniformly negative for 2008, 2009 and 2010. The most prominent effect of the financial crisis on the PV industry has been higher financing costs, so other constituent expenses, including module prices, must decline to maintain constant margins and returns for developers and investors, respectively.

\footnotetext{
${ }^{33}$ Although the estimates do not always specify whether module prices are presented in real or nominal terms, the impact from inflation is minor given the four-year time horizon.
} 


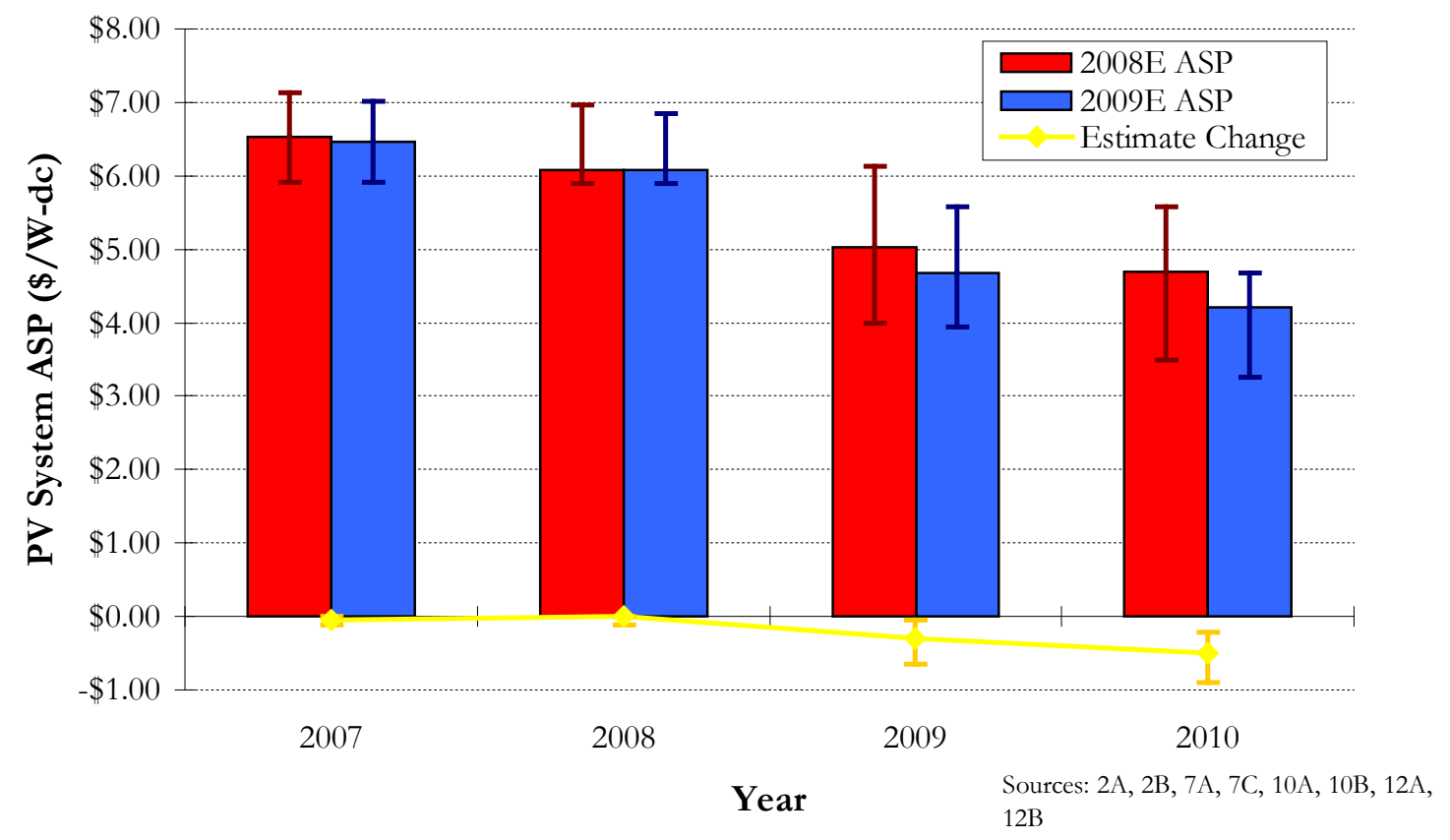

Figure 16. Average PV system prices ${ }^{34}$

Figure 16 shows the forecasted average system prices and estimate changes through 2010 . The recent median projections are that system prices will decrease from $\$ 6.08 /$ Watt in 2008 to $\$ 4.21 /$ Watt in 2010, a CAGR of -17\%. As is the case with module prices, the Q1 2009 forecasted system price trend does not substantially differ from that expected in Q3 2008, in which the 20082010 CAGR was $-12 \%$. The reasons for the downward price movement for systems are the same as those for modules, increases in production capacity across the supply chain outpacing demand growth and subsidies falling over time. ${ }^{35}$ Lastly, the downward shift in median forecasts between Q3 2008 and Q1 2009 as well as the negative estimate changes reflects the higher financing costs resulting from the credit crisis.

\section{Addendum: Q3 2009 PV Forecasts}

While various developments have impacted the outlook of the PV industry since the Q1 2009 forecasts were made, the most dramatic change has been the reduction of prices throughout the PV supply chain. The extent to which prices have fallen from Q1 through the middle of Q3 2009, as well as the recently-forecasted price declines through 2010, has significantly exceeded what industry analysts expected in the beginning of the year. The additional drops in prices have important impacts on the dynamics of the PV industry.

\footnotetext{
${ }^{34}$ Although the estimates do not always specify whether system prices are presented in real or nominal terms, the impact from inflation is minor given the four-year time horizon.

${ }^{35}$ However, the declines in recent median forecasted prices for 2009 versus 2008 is more pronounced for PV modules ($30 \%$ year/year) than for systems (-23\% year/year). This difference is likely the result of greater inventories and overcapacity within module production than that which exists in the system integrator and developer segment.
} 
At the start of 2009, the spot price of polysilicon was roughly $\$ 150 / \mathrm{kg} .{ }^{36}$ In the March 2009 survey shown in Figure 14, the average contract price for polysilicon delivery in 2009 was $\$ 107 / \mathrm{kg}$. However, the spot price dropped to $\$ 74 / \mathrm{kg}$ in May and $\$ 70 / \mathrm{kg}$ in August. ${ }^{37}$ It is worth noting that in the March survey, a polysilicon price of $\$ 70 / \mathrm{kg}$ was not reached until 2012 . While polysilicon prices have appeared to stabilize over the summer, given that production costs at REC, Hemlock and Wacker Chemie are estimated to be below $\$ 30 / \mathrm{kg}$, there is significant room for further price erosion as new capacity comes online. ${ }^{38}$ The low current polysilicon prices and potentially even lower future prices will further hinder the prospects of the less-pure UMG-Si.

For PV modules, which had averaged approximately $\$ 3.75 / \mathrm{W}$ in 2008 , as shown in Figure 15 , the reduction in price has also been dramatic. While the median Q1 2009 estimate for average PV module price in 2009 was just over $\$ 2.60$, by June, prices had already fallen to $\$ 2.40-\$ 3.00$ for c-Si modules and $\$ 1.70$ for CdTe modules. ${ }^{39}$ Unlike prices for polysilicon, PV module prices continued to decline during the summer, dropping to $\$ 1.90-\$ 2.60$ for c-Si modules and $\$ 1.60$ for CdTe modules by mid-August. ${ }^{40}$ The significant range for c-Si modules reflects Chinese suppliers on the low end, which have put considerable pricing pressure on European, U.S. and Japanese module producers. Based on historical price differences between suppliers, a $30 \%+$ price premium for top-tier brands is unlikely to be sustained.

While the range between Chinese and European, U.S. and Japanese module producers has increased in percentage terms, the difference between average c-Si prices and CdTe prices (from First Solar), has narrowed considerably. Given their lower efficiency, CdTe modules need to be priced 25-30 cents below c-Si modules to generate equivalent project returns. ${ }^{41}$ The drop in c-Si prices prompted First Solar to institute a rebate program in Germany to maintain its sales growth. With a recently-projected average c-Si module price of $\$ 1.60$ in 2010 (far below the median Q1 2009 estimate of $\$ 2.45$ for the average module price in 2010), CdTe modules will have to sell around $\$ 1.35$ next year. ${ }^{42}$ This pricing pressure from c-Si modules will be even more intense on a$\mathrm{Si}$, which is less efficient than CdTe, and on CIGS, being the least established technology. Whether thin film PV will continue to gain market share, as projected in Q1 2009 (Figure 6), is now less probable.

\section{Conclusion}

The financial crisis has had a significant impact on the PV industry, primarily through increasing the cost and reducing the availability of investment into the sector. These effects have been more immediately experienced by PV installations than by production facilities, due to the different types and duration of investments, and thus PV demand has been reduced by a greater proportion than PV production. More expensive financing is also directly reflected in PV module

\footnotetext{
${ }^{36}$ New Energy Finance Solar Spot Survey, August 2009.

${ }^{37}$ Ibid.

${ }^{38}$ Ibid.

${ }^{39}$ UBS Investment Research, Global Solar Industry Update. August 19, 2009.

${ }^{40}$ Ibid.

${ }^{41}$ Deutsche Bank, First Solar: Stellar 2 Q09 performance; spurring $2 H 09$ demand. July 30, 2009.

${ }^{42}$ Deutsche Bank, First Solar: Resetting 2010 expectations. August 19, 2009.
} 
and system price declines, as other constituent costs have had to decline to maintain necessary rates of return for PV installations.

Furthermore, in regards to pricing, the financial crisis has had the effect of accelerating a downward trend that was forecasted well before the tightening of credit to the sector. With the substantial ramp in capacity across the PV supply chain beginning several years ago, it was evident that the production shortfalls and bottlenecks which existed in the beginning of 2008 would disappear as supply came on line. By reducing demand more than production, the financial crisis has accelerated previously-expected PV overcapacity and resulting price declines. However, the extent of the price declines for c-Si modules has been far beyond what industry analysts had anticipated.

While the further decline in module prices will increase the returns on investments in PV systems, leading to more installations, the current demand picture is complicated by the uncertain nature of public policies that incentivize PV. For example, the importation of lower-priced Chinese modules generated pre-election opposition in Germany to the level of the country's feed-in-tariff. ${ }^{43}$ On the other hand, China and India have both recently announced incentive programs and targets for PV installations, but their near-term impact is unclear.

\section{References}

1A) Cowen \& Co. Industry Outlook: Global PV Supply/Demand. August 28, 2008.

1B) Cowen \& Co. Industry Outlook: Industry Hoping for Help from Stimulus Bill. January 12, 2009.

2A) Morgan Stanley. Solar Devices: Dislocation and Inflection. November 14, 2008.

2B) Morgan Stanley. Solar Devices: Dislocation - Industry Reset. March 24, 2009.

3A) Prometheus Institute for Sustainable Development and PV Energy Systems. Photovoltaic Markets, Technology, Performance, and Cost to 2015. Presented at Solar Power International. October 13, 2008.

3B) Greentech Media Inc. and Prometheus Institute for Sustainable Development. PV Technology, Production, and Cost, 2009 Forecast: The Anatomy of a Shakeout. January 2009.

4A) Thomas Weisel Partners. Alternative Energy: Solar Demand Very Uncertain Entering 2009 Given Tight Credit Conditions; Oversupply Lurking Right Around the Corner. October 13, 2008.

4B) Thomas Weisel Partners. Alternative Energy; Presentation Materials to Investors. April 2009.

5A) Oppenheimer \& Co. PV Market Forecast. September 2008.

5B) Oppenheimer \& Co. PV Market Forecast. April 2009.

6A) Lehman Brothers. Solar Insights 4: Solar Demand Analysis. September 9, 2008.

6B) Barclays Capital. 2009 Solar Demand Outlook. March 23, 2009.

${ }^{43}$ Deutsche Bank, Rising negative media bias on German Solar FITs. August 17, 2009. 
6C) Barclays Capital. Solar Energy Handbook: The Second Growth Phase of Solar Era. May 1, 2009.

7A) Deutsche Bank. Solar Photovoltaic Industry: Solar PV Industry Outlook and Economics. May $27,2008$.

7B) Deutsche Bank. Solar Photovoltaic Industry: Looking Through the Storm. January 21, 2009.

7C) Deutsche Bank. Personal Communication. May 2009.

8A) New Energy Finance. Insight Services: Tough Times for PV Manufacture. October 28, 2008.

8B) New Energy Finance. PV Market Outlook: It's Darkest Before the Dawn. March 31, 2009.

8C) New Energy Finance. New Energy Finance Silicon and Wafer Price Index. December 2008.

8D) New Energy Finance. New Energy Finance Silicon and Wafer Price Index. March 2009.

9A) Citi Investment Research. US Solar Stocks: Market Forecast. October 21, 2008.

9B) Citi Investment Research. US Solar Stocks: Inventory Has Yet to Peak, so It's Still Too Early. March 6, 2009.

10A) Lazard Capital Markets. Solar Sector: 3Q Preview. November 4, 2008.

10B) Lazard Capital Markets. A Framework for Assessing Solar Stocks in Turbulent Times. April 2, 2009.

11A) Navigant Consulting. Photovoltaic Manufacturer Shipments \& Competitive Analysis 2007/2008 (i - Conservative Scenario; ii - Accelerated Scenario). April 2008.

11A) Navigant Consulting. Photovoltaic Manufacturer Shipments \& Competitive Analysis 2008/2009 (i - Conservative Scenario; ii - Accelerated Scenario). April 2009.

12A) Lux Research. Solar State of the Market Q3 2008: The Rocky Road to \$100 billion. September 2008.

12B) Lux Research. Finding the Solar Market's Nadir. February 2009.

13A) UBS Investment Research. Global Recession Impacting Solar's Growth. October 28, 2008.

13B) UBS Investment Research. Darwin's Theory - Survival of the Fittest. February 26, 2009. 


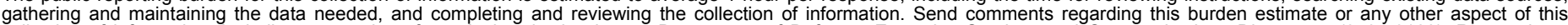

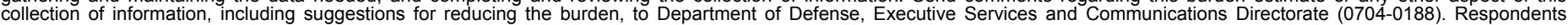

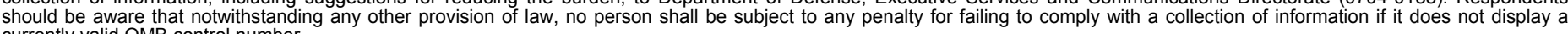

PLEASE DO NOT RETURN YOUR FORM TO THE ABOVE ORGANIZATION.
1. REPORT DATE (DD-MM-YYYY) September 2009
4. TITLE AND SUBTITLE
The Effects of the Financial Crisis on Photovoltaics: An Analysis of Changes in Market Forecasts from 2008 to 2009

3. DATES COVERED (From - To)

5a. CONTRACT NUMBER

DE-AC36-08-GO28308

5b. GRANT NUMBER

5c. PROGRAM ELEMENT NUMBER

5d. PROJECT NUMBER

NREL/TP-6A2-46713

5e. TASK NUMBER

PVD9.1210

5f. WORK UNIT NUMBER
7. PERFORMING ORGANIZATION NAME(S) AND ADDRESS(ES)

National Renewable Energy Laboratory

1617 Cole Blvd.

Golden, CO 80401-3393

\section{PERFORMING ORGANIZATION REPORT NUMBER \\ NREL/TP-6A2-46713}

9. SPONSORING/MONITORING AGENCY NAME(S) AND ADDRESS(ES)

\section{SPONSOR/MONITOR'S ACRONYM(S)} NREL

11. SPONSORING/MONITORING AGENCY REPORT NUMBER

12. DISTRIBUTION AVAILABILITY STATEMENT

National Technical Information Service

U.S. Department of Commerce

5285 Port Royal Road

Springfield, VA 22161

\section{SUPPLEMENTARY NOTES}

\section{ABSTRACT (Maximum 200 Words)}

To examine how the financial crisis has impacted expectations of photovoltaic production, demand and pricing over the next several years, we surveyed the market forecasts of industry analysts that had issued projections in 2008 and 2009. We find that the financial crisis has had a significant impact on the PV industry, primarily through increasing the cost and reducing the availability of investment into the sector. These effects have been more immediately experienced by $P V$ installations than by production facilities, due to the different types and duration of investments, and thus PV demand has been reduced by a greater proportion than $\mathrm{PV}$ production. By reducing demand more than production, the financial crisis has accelerated previously expected PV overcapacity and resulting price declines.

\section{SUBJECT TERMS}

solar photovoltaics; solar energy; PV; analysis; NREL; financial crisis; PV industry; PV production; PV pricing; PV demand; PV market; PV installations; Robert M. Margolis; John E. Bartlett; Charles E. Jennings

\begin{tabular}{l|l|l|}
\hline 16. SECURITY CLASSIFICATION OF: \\
\hline $\begin{array}{l}\text { a. REPORT } \\
\text { Unclassified }\end{array}$ & $\begin{array}{c}\text { b. ABSTRACT } \\
\text { Unclassified }\end{array}$ & $\begin{array}{l}\text { c. THIS PAGE } \\
\text { Unclassified }\end{array}$ \\
& & \\
\hline
\end{tabular}

\begin{tabular}{c|c} 
17. LIMITATION \\
OF ABSTRACT \\
UL
\end{tabular}

19a. NAME OF RESPONSIBLE PERSON

Standard Form 298 (Rev. 8/98) Prescribed by ANSI Std. Z39.18 